\title{
A new strategy to fight antimicrobial resistance: the revival of old antibiotics
}

\author{
Nadim Cassir ${ }^{1,2}$, Jean-Marc Rolain ${ }^{1}$ and Philippe Brouqui ${ }^{1,2 *}$ \\ ${ }^{1}$ Unité de Recherche sur les Maladies Infectieuses et Tropicales Emergentes, UM63 CNRS 7278 IRD 198 INSERM U1095, Facultés de Médecine et de Pharmacie, \\ Aix-Marseille Université, Marseille, France \\ 2 Institut Hospitalo-Universitaire en Maladies Infectieuses et Tropicales, Hôpital Nord, Assistance Publique - Hôpitaux de Marseille, Marseille, France
}

Edited by:

Faraj Barah, University of Kalamoon, Syria

Reviewed by:

Patrick Rik Butaye, Ghent University, Belgium

Noton Kumar Dutta, Johns Hopkins University, USA

\section{*Correspondence:}

Nadim Cassir and Philippe Brouqui, Institut Hospitalo-Universitaire en Maladies Infectieuses et Tropicales, Hôpital Nord, Assistance Publique Hôpitaux de Marseille, Chemin des Bourrelys, 13915 Marseille Cedex 20, France

e-mail: cassirnadim@gmail.com;

philippe.brouqui@univ-amu.fr
The increasing prevalence of hospital and community-acquired infections caused by multidrug-resistant (MDR) bacterial pathogens is limiting the options for effective antibiotic therapy. Moreover, this alarming spread of antimicrobial resistance has not been paralleled by the development of novel antimicrobials. Resistance to the scarce new antibiotics is also emerging. In this context, the rational use of older antibiotics could represent an alternative to the treatment of MDR bacterial pathogens. It would help to optimize the armamentarium of antibiotics in the way to preserve new antibiotics and avoid the prescription of molecules known to favor the spread of resistance (i.e., quinolones). Furthermore, in a global economical perspective, this could represent a useful public health orientation knowing that several of these cheapest "forgotten" antibiotics are not available in many countries. We will review here the successful treatment of MDR bacterial infections with the use of old antibiotics and discuss their place in current practice.

Keywords: multi-drug-resistant pathogens, MRSA and VRE, ESBLs, colistin, fosfomycin, trimethoprimsulfamethoxazole combination, tetracycline, MDR-tuberculosis

\section{INTRODUCTION}

Antimicrobial resistance is one of the greatest threats to human health worldwide (Walker et al., 2009). It dramatically reduces the probability of effectively treating infections and increases the morbidity and mortality associated with common bacterial diseases (Klevens et al., 2007). Since the discovery of penicillin in 1928, antimicrobial resistance has been linked to antibiotic use. Recent studies of bacteria in permafrost samples documented the existence of resistance genes 30,000 years ago (D'Costa et al., 2011), emphasizing that antibiotic use and misuse favor resistance through selection pressure (Rolain et al., 2013). It has been demonstrated that antimicrobial resistance prevalence can be diminished through decreased antibiotic consumption (Seppälä et al., 1997). This complex ecological phenomenon depends on individuals, bacterial strains, and mechanisms of resistance (Andersson and Hughes, 2010). Old and new antibiotics vary in their impact on the emergence and spread of resistant bacteria (Sullivan et al., 2001).

Bacterial strains resistant to newly developed antibiotics have emerged recurrently (Long and Vester, 2012). Therefore, antimicrobial resistance presents an ongoing challenge that requires a multifaceted approach including (i) biomedical innovation, (ii) improved surveillance of antibiotic consumption and antimicrobial-resistance rates, (iii) prevention of health-careassociated infections and transmission of multidrug-resistant (MDR) bacteria and environmental dissemination, (iv) rapid microbiological diagnosis, and (v) curtailed clinical and veterinary misuse. It is alarming that although bacterial resistance continues to emerge, the rate at which antibiotics are being developed is decreasing. In this context, the reintroduction of previously used antibiotics active against MDR bacteria represents a new alternative for the control of antimicrobial resistance (Pulcini et al., 2012). As old antibiotics have rarely been subjected to contemporary drug-development procedures or compared to commonly used antibiotics, they are less considered in practice guidelines. Therefore, their efficacy and safety must be revaluated to optimize therapy.

This review aims at providing a non-exhaustive collection of microbiological and clinical data on potentially useful older antibiotics. We consider the value of "forgotten" antibiotics for the treatment of (i) MDR Gram-negative bacterial infections (polymyxins, fosfomycin, mecillinam, temocillin, and nitrofurantoin); (ii) MDR Gram-positive infections [trimethoprimsulfamethoxazole (TMP/SMX), tetracyclines, chloramphenicol, clindamycin, pristinamycin, rifampicin, and fusidic acid]; and (iii) MDR tuberculosis (clofazimine, amoxicilline-clavulanate, TMP/SMX, and minocycline).

\section{FORGOTTEN ANTIBIOTICS FOR MULTIDRUG-RESISTANT GRAM-NEGATIVE BACTERIA}

The incidence of infections caused by MDR Gram-negative bacteria has increased worldwide over the last decade. The majority of Escherichia coli and Klebsiella pneumoniae isolates reported by European Antimicrobial Resistance Surveillance Network (EARSNet) in 2012 were resistant to at least one of the antimicrobials tested, and many had combined resistance to third-generation cephalosporins, fluoroquinolones, and aminoglycosides (http:// www.ecdc.europa.eu). Of particular importance to public health 
is the spread beta-lactamases with an extended spectrum, which confer resistance to most $\beta$-lactams (even carbapenems for some of them) and are frequently associated with resistance to other groups of antibiotics in isolates of Enterobacteriaceae both from community and health-care settings (Pitout and Laupland, 2008; Zahar et al., 2009; Diene et al., 2013). In this context, it is essential to optimize our antibacterial armamentarium. One major step is to reconsider currently active and available antibiotics. Table 1 summarizes the successful clinical treatment of infections caused by MDR Gram-negative bacteria with "forgotten" antibiotics, either alone or in combination.

\section{POLYMYXINS}

Colistin, synthesized by Paenibacillus polymyxa subspecies colistinus, was discovered in 1949 (Komura and Kurahashi, 1979). Polymyxin B and polymyxin E (colistin) are the 2 polymyxins used in clinical practice. Their mechanism of action includes attachment to the outer cell membrane of Gram-negative

Table 1 | Infections caused by multidrug-resistant Gram-negative bacteria successfully treated with old antibiotics.

\begin{tabular}{|c|c|c|c|}
\hline Molecule & Pathogens & Sites of infection & References \\
\hline $\begin{array}{l}\text { Colistin } \\
\text { (IV) }\end{array}$ & $\begin{array}{l}\text { MDR A. baumannii } \\
\text { MDR P. aeruginosa } \\
\text { MDR K. pneumonia } \\
\text { MDR S. maltophilia }\end{array}$ & $\begin{array}{l}\text { VAP } \\
\text { HA-pneumonia } \\
\text { UTI } \\
\text { IAI } \\
\text { BJI } \\
\text { Bacteremia } \\
\text { Wound infection } \\
\text { Meningitis } \\
\text { PJI } \\
\text { Diabetic foot infection }\end{array}$ & $\begin{array}{l}\text { Jiménez-Mejías et al., 2002; Garnacho-Montero et al., 2003; } \\
\text { Linden et al., 2003; Markou et al., 2003; Fulnecky et al., 2005; } \\
\text { Kasiakou et al., 2005a,b; Falagas et al., 2006a,b; Motaouakkil } \\
\text { et al., 2006; Tascini et al., 2006; Kallel et al., 2007; Koomanachai } \\
\text { et al., 2007; Rios et al., 2007; Bassetti et al., 2008; Betrosian } \\
\text { et al., 2008; Mastoraki et al., 2008; Song et al., 2008; Taşbakan } \\
\text { et al., 2009; Kofteridis et al., } 2010\end{array}$ \\
\hline $\begin{array}{l}\text { Fosfomycin } \\
\text { (IV) }\end{array}$ & $\begin{array}{l}\text { ESBL E. coli } \\
\text { ESBL } \\
\text { K. pneumonia/Enterobacter } \\
\text { sp./Serratia sp. } \\
\text { MDR P. aeruginosa } \\
\text { OXA-48 K. pneumonia and } \\
\text { E. coli } \\
\text { KPC K. pneumonia } \\
\text { Carbapenem-resistant } P \text {. } \\
\text { aeruginosa } \\
\text { MDR S. enterica serotype } \\
\text { Typhimurium }\end{array}$ & $\begin{array}{l}\text { VAP } \\
\text { HA-pneumonia } \\
\text { UTI } \\
\text { IAI } \\
\text { BJI } \\
\text { Bacteremia } \\
\text { Wound infection } \\
\text { Meningitis } \\
\text { Brain abscess } \\
\text { Lung abscess } \\
\text { Cystic fibrosis (pulmonary } \\
\text { exacerbation) }\end{array}$ & $\begin{array}{l}\text { Mirakhur et al., 2003; Nakaya et al., 2003; Michalopoulos et al., } \\
\text { 2010; Apisarnthanarak and Mundy, 2012; Dinh et al., 2012; } \\
\text { Karageorgopoulos et al., 2012; Navarro-San Francisco et al., } \\
\text { 2013; Pontikis et al., } 2014\end{array}$ \\
\hline
\end{tabular}

\begin{tabular}{|c|c|c|c|}
\hline $\begin{array}{l}\text { Fosfomycin } \\
\text { (PO) }\end{array}$ & $\begin{array}{l}\text { ESBL E. coli and } \\
\text { K. pneumoniae } \\
\text { KPC K. pneumoniae } \\
\text { MDR P. aeruginosa }\end{array}$ & Lower UTI & Pullukcu et al., 2007; Senol et al., 2010; Neuner et al., 2012 \\
\hline $\begin{array}{l}\text { Pivmecillinam } \\
\text { Mecillinam } \\
\text { (PO) }\end{array}$ & $\begin{array}{l}\text { ESBL E. coli and } \\
\text { K. pneumonia } \\
\text { CTX-M/ESBL E. coli } \\
\text { ESBL Enterobacteriaceae }\end{array}$ & $\begin{array}{l}\text { Lower UTI } \\
\text { Relapsing pyelonephritis } \\
\text { Complicated UTI }\end{array}$ & $\begin{array}{l}\text { Nicolle and Mulvey, 2007; Titelman et al., 2012; Jansåker et al., } \\
\text { 2014; Søraas et al., } 2014\end{array}$ \\
\hline $\begin{array}{l}\text { Temocillin } \\
\text { (IV) }\end{array}$ & $\begin{array}{l}\text { dAmpC/ESBL } \\
\text { Enterobacteriaceae } \\
\text { ESBL E. coli and } \\
\text { K. pneumonia } \\
\text { MDR P. agglomerans }\end{array}$ & $\begin{array}{l}\text { HA pneumonia } \\
\text { UTI } \\
\text { Bacteremia } \\
\text { Severe sepsis (VAP, UTI, IAI) } \\
\text { Epidural abscess } \\
\text { Subacute synovitis }\end{array}$ & $\begin{array}{l}\text { Barton et al., 2008; Duerinckx, 2008; Gupta et al., 2009; } \\
\text { Balakrishnan et al., } 2011\end{array}$ \\
\hline $\begin{array}{l}\text { Nitrofurantoin } \\
\text { (PO) }\end{array}$ & ESBL E. coli & Lower UTI & Tasbakan et al., 2012 \\
\hline
\end{tabular}

MDR, Multidrug-resistant; P. aeruginosa, Pseudomonas aeruginosa; A. baumanii, Acinetobacter baumanii; E. coli, Escherichia coli; K. pneumonia, Klebsiella pneumoniae; S. enterica, Salmonella enterica; P. agglomerans, Pantoea agglomerans; VAP, Ventilator-associated pneumonia; HA, Hospital-acquired; UTI, Urinary-tract infection; BJI, Bone and joint infection; PJI, Prosthetic-joint infection; IAl, Intra-abdominal infection; ESBL, Extended-spectrum $\beta$-lactamases; IV, Intravenous; PO, Peros. 
bacteria, leading to membrane-permeability changes and cell death. Colistin was initially used in Japan and in Europe during the 1950s and was used in the United States in the form of colistimethate sodium in 1959 (Reed et al., 2001). Intravenous formulations of colistin and polymyxin B were gradually abandoned in most parts of the world in the early 1980s because of the reported high incidence of nephrotoxicity (Biswas et al., 2012). Indeed, most of the drug is excreted in the urine, and dose adjustment is required in patients with renal failure. Recent studies have shown that better management of intravenous formulations led to considerably less toxicity than was reported in old studies (Falagas and Kasiakou, 2005). Inhaled colistin has been proposed as alternative, in adjunction to systemic therapy or alone, for the treatment of pneumonia or chronic lung infection with MDR Gram-negative bacteria (Lu et al., 2012; Tumbarello et al., 2013). Although promising results have been reported, more data are needed to establish its appropriate role in mechanically-ventilated patients (Michalopoulos and Falagas, 2014).

Colistin was recommended by the most recent American Thoracic Society Guidelines as a therapeutic option for the treatment of ventilator-associated pneumonia (VAP) caused by MDR Gram-negative organisms (American Thoracic Society, and Infectious Diseases Society of America, 2005). Intravenous polymyxins has been evaluated for the treatment of serious MDR $P$. aeruginosa, Acinetobacter baumannii and Enterobacteriaceae infections of various types, including pneumonia, bacteremia, abdominal infections, bone and joint infections (BJIs), urinarytract infections (UTIs), and meningitis (Falagas and Kasiakou, 2005) (Table 1).

One worrisome problem is the emergence of colistin resistance in KPC-producing bacteria, as seen in up to $20 \%$ of isolates in some countries (Kontopidou et al., 2014). The spread of colistin resistance may be related to the extensive use of this drug in empiric and targeted treatment and also due to the ecological effect of topical use in selective decontamination protocols in intensive-care units (Oostdijk et al., 2013). But, the most common mechanism of colistin resistance is modification of LPS (Park et al., 2011). As it chromosomal, it is not prone to spread horizontally, but relies exclusively on clonal expansion. Several other mechanisms have been suggested, most of which involve changes in the outer membrane (Li et al., 2006). Paenibacillus polymyxa subspecies colistinus, also produces colistinase, which inactivates colistin. However, enzymatic resistance of bacteria to colistin has not been reported in clinical practice (Falagas and Kasiakou, 2005). Interestingly, decades of colistin use in veterinary medicine has not been associated with an increased resistance prevalence in commensal Escherichia coli isolated from animals (Wasyl et al., 2013). Regarding Acinetobacter baumanii, colistin resistance has emerged worldwide (Cai et al., 2012). Although it associated with impaired virulence (Rolain et al., 2011), combination therapy might be the best antimicrobial strategy. Besides, optimization of colistin use should prevent the emergence of species naturally resistant to colistin, such as $S$. marcescens and $P$. mirabilis, which have the potential to cause outbreaks (Merkier et al., 2013).

\section{FOSFOMYCIN}

Fosfomycin is an antimetabolite inhibitor that prevents the formation of $\mathrm{N}$-acetylmuramic acid, an essential precursor of peptidoglycan-chain formation in the bacterial wall. It was first identified in Spain in 1969 in the fermentation broths of several strains of Streptomyces sp. (Raz, 2012). Fosfomycin has a broad spectrum of antimicrobial activity, including a rapid bactericidal effect against several Gram-negative and Gram-positive aerobic bacteria (Falagas et al., 2009). Unlike many alternatives, fosfomycin formulations are generally well tolerated, with minimal toxicity (excepting thrombophlebitis when administered via peripheral venous catheter).

The use of intravenous fosfomycin formulations for the treatment of infections caused by MDR bacteria has shown a high rate of clinical success (Table 1). For lower UTIs, the successful use of oral fosfomycin tromethamine is well documented.

One of the first studies on the broad use of fosfomycin in Spain noted development of resistance in 3\% of the 959 cases in total but in $10 \%$ of the 86 P. aeruginosa infections (Rodríguez et al., 1977). These rates of emergence appear to be stable over time in countries where fosfomycin use has been used for decades (Falagas et al., 2008). But, fosfomycin resistance is in many bacterial species caused by plasmid-mediated fosfomycin genes (Suárez and Mendoza, 1991). Currently, plasmid-mediated fosfomycin resistance determinants, have been discovered and are related to fosfomycin resistance in Escherichia coli (fosA, fosA3, fos C) (Lee et al., 2012), Enterobacter cloacae (fosA2) (Xu et al., 2011), Klebsiella pneumoniae (fosA, fosA3) (Lee et al., 2012), Staphylococcus spp. (fosB) (Suárez and Mendoza, 1991), and, Enterococcus faecium (fosB3) (Xu et al., 2013). Chromosomally resistant mutants have also been well described (Suárez and Mendoza, 1991). This is a major concern about the potential for the selection and spread of resistance. Then, when used to treat systemic infections, intravenous fosfomycin may be a component of combination therapy administered (Pogue et al., 2011).

\section{PIVMECILLINAM/MECILLINAM}

Pivmecillinam is the prodrug of mecillinam, a unique $\beta$-lactam with high specificity against penicillin-binding protein 2 (PBP2 ) in the Gram-negative cell wall and therefore is highly active against Enterobacteriaceae and resistant to $\beta$-lactamases. This drug for oral use is well tolerated and can be given in patients with impaired renal function, but its usefulness is limited by its lack of activity against Gram-positive organisms and Pseudomonas aeruginosa (Dewar et al., 2014). Since its introduction in the 1970s, it has been widely used for the treatment of acute lower UTIs, primarily in the Nordic countries (Graninger, 2003).

Treatment of lower UTIs caused by ESBL-producing E. coli has produced variable results (Titelman et al., 2012; Poulsen et al., 2013; Søraas et al., 2014) (Table 1). The high rates of treatment failure $(44 \%)$ reported by Søraas et al. raised concerns regarding the optimal dosing that suggest the need for further studies (Søraas et al., 2014). Treatment with pivmecillinam was successful in a case of relapsing pyelonephritis caused by ESBL-producing E. coli where other treatments had failed (Nicolle and Mulvey, 2007). Currently, the use of pivmecillinam as firstline treatment for uncomplicated UTIs is recommended by the Infectious Diseases Society of America and the European Society for Microbiology and Infectious Diseases (Gupta et al., 2011).

The widespread and long-term use of pivmecillinam for UTIs in Scandinavian countries is well documented, with no indication 
of any significant increase in mecillinam resistance in these countries (Graninger, 2003). Indeed, Pivmecillinam is a prodrug and thus has a low impact on the endogenous microflora (Sullivan et al., 2001). Although poorly studied, mecillinam resistance have been shown to be caused by mutations in the genes affecting the elongation process of the bacteria, and associated with substantial fitness cost in vitro to the resistant E. coli (Wachi et al., 1987). These properties lead to a decreased potential for the selection of resistance.

\section{TEMOCILLIN}

Developed and first marketed in the UK in the 1980s, temocillin was quickly abandoned because its lack of activity against Grampositive organisms, anaerobes and Pseudomonas aeruginosa was perceived as a major limitation (Slocombe et al., 1981). This beta lactam antibiotic, that is the $6-\alpha$-methoxy derivative of ticarcillin, is also characterized by its resistance to most beta-lactamases with an extended spectrum (i.e., TEM, SHV, CTX-M, AmpC) and some carbapenemases (Livermore et al., 2006; RodriguezVillalobos et al., 2006; Glupczynski et al., 2007; Adams-Haduch et al., 2009). Temocillin is mainly excreted renally and therefore requires dosage adjustment in patients with renal impairment.

Based on temocillin's relatively narrow spectrum, it is appropriate for use in microbiologically directed therapy, particularly for the UTIs caused by confirmed ESBL producers. In this setting, temocillin might be used as an alternative to carbapenems (Livermore and Tulkens, 2009), as temocillin is ecologically safer. Research in Belgium suggests that temocillin is also effective in severe infections such as VAP if the organism appears susceptible in vitro (De Jongh et al., 2008). It is also a potential alternative treatment option for mild-to-moderate UTIs caused by KPC-producing Enterobacteriaceae (Adams-Haduch et al., 2009).

The first reported case of breakthrough bacteremia during temocillin treatment occurred in a patient with renal dysfunction and probable insufficient dosing ( $1 \mathrm{~g}$ once daily) (Gupta et al., 2009). NDM-1 and OXA-48 carbapenemases also confer resistance to temocillin (Livermore et al., 2011). Although poorly studied, the main mechanisms of resistance to temocillin are efficient efflux or reduced PBP binding that could explain high MICs to Pseudomonas aeruginosa (Livermore and Tulkens, 2009).

\section{NITROFURANTOIN}

Nitrofurantoin (NFT), which is a synthetic antimicrobial derived from furan by the addition of a nitro group and a side chain containing hydantoin, was introduced into clinical practice in its microcrystalline form in 1952. Since the macrocristalline form was developed, the previously frequent gastrointestinal side effects have become less common, giving this drug a good safety profile (Cunha, 1989). This molecule has a broad-spectrum activity against the main uropathogens (i.e., Escherichia coli, Citrobacter species, group-B streptococci, enterococci, Staphylococcus aureus, S. epidermidis, Klebsiella pneumonia, and Enterobacter sp.) and has also been shown to be active against ESBL-producing Enterobacteriaceae and vancomycin-resistant enterococci. Notably, it lacks activity against Pseudomonas aeruginosa, Serratia marscecens, and Proteus mirabilis (Cunha et al., 2011).
NFT is effective both in vitro and in clinical studies against ESBL-producing E. coli (Table 1); however, given that patients with acute pyelonephritis respond inconsistently to NFT and that bacteremia has occurred during NFT treatment, its use has been restricted to lower UTIs (Tasbakan et al., 2012). Currently, NFT is recommended as a first-line treatment for uncomplicated UTIs by the Infectious Diseases Society of America and the European Society for Microbiology and Infectious Diseases (Gupta et al., 2011).

Recent surveys have found a persistent low prevalence of resistance to NFT (1.9-7.7\%) among urinary E. coli isolates, including those resistant to TMP/SMX or ciprofloxacin; the prevalence of this resistance reaches $23.2 \%$ in ESBL-producing E. coli (Tasbakan et al., 2012). Chromosomally resistance-conferring mutations have been identified in the $n s f A$ and $n s f B$ genes that encode oxygen-insensitive nitroreductases, and associated with substantial fitness cost in vitro to the resistant E. coli (Sandegren et al., 2008). These properties lead to a decreased potential for the selection of clinically relevant resistance.

\section{FORGOTTEN ANTIBIOTICS FOR MULTIDRUG-RESISTANT GRAM-POSITIVE BACTERIA}

Staphylococcus aureus and Enterococcus spp. are two of the most common organisms causing nosocomial infections and are consistently associated with high mortality rates (Pea and Viale, 2007). Resistance among these pathogens to first-line agents such as methicillin and vancomycin continues to rise, while isolates with reduced susceptibility to newer agents, including linezolid, are also emerging (Patel et al., 2013). In Table 2, we summarized the successful clinical treatment of infections caused by MDR Gram-positive bacteria with "forgotten" antibiotics alone or in combination.

\section{TRIMETHOPRIM-SULFAMETHOXAZOLE}

The combination drug TMP/SMX acts as a broad-spectrum bactericidal agent and was introduced clinically in the early 1970s (Grim et al., 2005). Trimethoprim is a tetrahydrofolate reductase inhibitor that, when added to sulfamethoxazole, provides a second-step block in the folate biosynthetic pathway (Proctor, 2008). According to its good oral bioavailability, highdosage regimen of TMP/SMX represents a suitable alternative for methicillin-resistant S. aureus (MRSA) infections (Muhammed Ameen et al., 2014).

TMP/SMX is recommended as first-line treatment for uncomplicated UTIs, skin and soft-tissue infections (SSTIs), and community-associated methicillin-resistant Staphylococcus aureus (CA-MRSA) infections, according to clinical practice guidelines (Gupta et al., 2011; Stevens et al., 2014). In a recent study with a cohort of 328 patients with infections due to MRSA with a MIC to vancomycin of $2 \mu \mathrm{g} / \mathrm{mL}$, TMP/SMX alone compared favorably to linezolid and daptomycin in terms of treatment efficacy, mortality, and reduced antibiotic costs (Campbell et al., 2012). Although TMP/SMX alone has been shown to be less effective than current treatment for MRSA endocarditis (i.e., vancomycin or teicoplanin) (de Górgolas et al., 1995), in combination with other antibiotics (i.e., daptomycin, clindamycin or vancomycin, and rifampicin) successful treatments have been 
Table 2 | Infections caused by multidrug-resistant Gram-positive bacteria successfully treated with old antibiotics.

\begin{tabular}{|c|c|c|c|}
\hline Molecule & Pathogens & Sites of infection & References \\
\hline $\begin{array}{l}\text { Trimethoprim- } \\
\text { sulfamethoxazole } \\
\text { (TMP/SMX) } \\
\text { (IV, PO) }\end{array}$ & $\begin{array}{l}\text { CA and HA-MRSA } \\
\text { E. americana }\end{array}$ & $\begin{array}{l}\text { SSTI } \\
\text { BJI } \\
\text { Osteomyelitis } \\
\text { IE (prosthetic valve) } \\
\text { Meningitis } \\
\text { Bacteremia } \\
\text { COPD exacerbation }\end{array}$ & $\begin{array}{l}\text { Shafqat et al., 1971; Seligman et al., 1973; Bengtsson et al., 1974; Tamer } \\
\text { and Bray, 1982; Levitz et al., 1984; Stein et al., 1998; Cenizal et al., 2007; } \\
\text { Pound et al., 2007; Nguyen et al., 2009; Goldberg et al., 2010; Cadena } \\
\text { et al., 2011; Messina et al., 2011; Di Carlo et al., } 2013\end{array}$ \\
\hline $\begin{array}{l}\text { Minocycline } \\
\text { (IV, PO) }\end{array}$ & MRSA & $\begin{array}{l}\text { SSTI } \\
\text { BJI } \\
\text { Osteomyelitis } \\
\text { IE (prosthetic valve) } \\
\text { Bacteremia }\end{array}$ & $\begin{array}{l}\text { Clumeck et al., 1984; Lawlor et al., 1990; Moreno et al., 1994; Ruhe } \\
\text { et al., 2005; Cenizal et al., 2007; Ruhe and Menon, } 2007\end{array}$ \\
\hline $\begin{array}{l}\text { Doxycycline } \\
\text { (IV, PO) }\end{array}$ & $\begin{array}{l}\text { MRSA } \\
\text { VREf }\end{array}$ & $\begin{array}{l}\text { SSTI } \\
\text { UTI } \\
\text { Bacteremia }\end{array}$ & \\
\hline $\begin{array}{l}\text { Chloramphenicol } \\
\text { (IV) }\end{array}$ & $\begin{array}{l}\text { VRE } \\
\text { VREf } \\
\text { S. maltophilia }\end{array}$ & $\begin{array}{l}\text { Meningitis } \\
\text { Ventriculitis } \\
\text { Bacteremia } \\
\text { IAI } \\
\text { El (prosthetic valve) }\end{array}$ & $\begin{array}{l}\text { Norris et al., 1995; Lautenbach et al., 1998; Pérez Mato et al., 1999; } \\
\text { Mehta et al., 2000; Ricaurte et al., 2001; Scapellato et al., } 2005\end{array}$ \\
\hline $\begin{array}{l}\text { Clindamycin } \\
(\mathrm{IV}, \mathrm{PO})\end{array}$ & $\begin{array}{l}\text { MRSA } \\
\text { MRSA (PVL+) }\end{array}$ & $\begin{array}{l}\text { SSTI } \\
\text { BJI } \\
\text { Mandible osteomyelitis } \\
\text { Necrotizing fasciitis } \\
\text { Necrotizing pneumonia } \\
\text { Bacteremia }\end{array}$ & $\begin{array}{l}\text { Martínez-Aguilar et al., 2003; Hidron et al., 2009; Tobeña Rué et al., } \\
\text { 2009; Tuzuner-Oncul et al., 2009; Kefala-Agoropoulou et al., } 2010\end{array}$ \\
\hline $\begin{array}{l}\text { Pristinamycin } \\
\text { (PO) }\end{array}$ & $\begin{array}{l}\text { MRSA } \\
\text { VRE } \\
\text { CONS }\end{array}$ & $\begin{array}{l}\text { Pneumonia } \\
\text { SSTI } \\
\text { UTI } \\
\text { BJI } \\
\text { Epidural abscess }\end{array}$ & $\begin{array}{l}\text { Dancer et al., 2003; Ng and Gosbell, 2005; Ruparelia et al., 2008; Reid } \\
\text { et al., } 2010\end{array}$ \\
\hline $\begin{array}{l}\text { Fusidic acid } \\
\text { (PO) }\end{array}$ & MRSA & $\begin{array}{l}\text { BJI } \\
\text { PJI } \\
\text { Chronic osteomyelitis } \\
\text { Epidural abscess }\end{array}$ & $\begin{array}{l}\text { Nather et al., 2005; Howden and Grayson, 2006; Aboltins et al., 2007; } \\
\text { Murray et al., 2008; Ahamed Puthiyaveetil, 2009; Ferry et al., 2010; } \\
\text { Chiang et al., 2011; O'Neill et al., 2011; Wolfe, } 2011\end{array}$ \\
\hline $\begin{array}{l}\text { Nitrofurantoin } \\
\text { (PO) }\end{array}$ & VRE $f$ & Chronic prostatitis & Taylor et al., 1998 \\
\hline $\begin{array}{l}\text { Fosfomycin } \\
\text { (PO) }\end{array}$ & VRE $f$ & Lower UTI & Neuner et al., 2012 \\
\hline $\begin{array}{l}\text { Fosfomycin } \\
\text { (IV) }\end{array}$ & $\begin{array}{l}\text { MRSA } \\
\text { CoNS }\end{array}$ & $\begin{array}{l}\text { Meningitis } \\
\text { IE } \\
\text { PJI }\end{array}$ & $\begin{array}{l}\text { De Boutin et al., 1985; Roualdes et al., 1985; Silbermann et al., 1995; } \\
\text { Lee et al., } 2013\end{array}$ \\
\hline
\end{tabular}

MRSA, methicillin-resistant Staphylococcus aureus; CA, community-associated; CoNS, coagulase-negative Staphylococci; VRE, vancomycin-resistant Enterococcus sp.; VREf, vancomycin-resistant Enterococcus faecium; S. maltophilia, Stenotrophomonas maltophilia; VAP, ventilator-associated pneumonia; IE, infective endocarditis; UTI, urinary-tract infection; BJI, bone and joint infection; PJI, prosthetic-joint infection; IAI, intra-abdominal infection; IV, Intravenous; PO, Per os.

reported (Fujino et al., 2009; Casalta et al., 2013; Di Carlo et al., 2013). Only one randomized, prospective trial compared TMPSMZ to vancomycin for the treatment of S. aureus (47\% MRSA) endovascular infections in injection-drug users. In this study,
TMP-SMZ was inferior to vancomycin only for the treatment of methicillin-susceptible $S$. aureus (MSSA), while the cure rates and other clinical and microbiological outcomes against the MRSA group were similar for both drugs (Markowitz et al., 1992). 
Long-term oral ambulatory treatment with TMP-SMZ appeared to be an effective alternative to the conventional medicosurgical treatment of chronic MDR Staphylococcus sp.-infected orthopedic implants (Stein et al., 1998). The scarcity of data concerning TMP-SMZ treatment for $S$. aureus infections emphasizes the need for further clinical studies comparing this drug to other available options, specifically vancomycin (Adra and Lawrence, 2004).

Over a 10-year period, interrupted time-series analysis demonstrated that the CA-MRSA period was associated with a significant increase in use of TMP/SMX but showed no significant changes in the rates of susceptibility among clinical isolates. There was also no evidence for selection of organisms with increased resistance to other antimicrobials in relation to increased TMP-SMZ use (Wood et al., 2012). Moreover, a recent report has shown high rates of susceptibility to TMPSMZ (94\%) in community-acquired MRSA (CA-MRSA) isolates (Chen et al., 2006). In another study, all 320 isolates of MRSA (97\% of USA300 strain) from outpatients with SSTIs were susceptible to TMP/SMZ (Moran et al., 2006). But this drug has also been considered to favor the selection and spread of resistant microorganisms on a population level. One study found that the mechanism was the selection for a class 1 integron, resulting in MDR Enterobacteriaceae in the intestinal flora of children (Van der Veen et al., 2009). Knowing that integrons are transferable genetic elements capable of expressing multiple resistance genes, the use of TMP-SMZ should be cautiously monitored regarding this potential collateral damage.

\section{TETRACYCLINES}

Chlortetracycline, from which tetracycline was derived in 1953, is produced by Streptomyces aureofaciens. In the late 1960s, the second-generation long-acting compounds doxycycline (in 1966) and minocycline (in 1967) were semi-synthetically derived and commercialized. Tetracyclines are a class of broad-spectrum bacteriostatic antibiotics active against Gram-positive and Gramnegative bacteria, as well as against intracellular organisms. These characteristics, together with the low cost and rarity of major side effects, have made tetracyclines a widely used class of antibiotics (Nelson and Levy, 2011). However, it should be noted that these drugs are contraindicated in pregnant woman, neonates, and young children because of their particular effects on skeletal growth and dentition (Demers et al., 1968).

Tetracyclines have been evaluated as an effective oral treatment option for patients with SSTIs caused by MRSA (Ruhe and Menon, 2007). Minocycline, associated with surgical drainage, resulted in rapid resolution of MRSA-associated cutaneous abscesses (Cunha, 2013). Doxycycline has intrinsic activity against enterococci, including VRE, and has been stated as an option for oral treatment of VRE cystitis (Heintz et al., 2010). Bacteremia caused by VRE has been successfully treated with doxycycline (Moreno et al., 1994).

Recently, a MDR strain of CA-MRSA genotype USA300 has emerged, with plasmids that confer resistance to tetracycline, macrolides, and clindamycin (Diep et al., 2008). Staphylococcal resistance to tetracyclines is mainly conferred by active reflux, which is mediated by plasmid-located tet $K$ and tet $L$ genes, and ribosomal protection, which is mediated by chromosomal or transposonal tet $M$ or tet $O$ genes (Trzcinski et al., 2000). Studies relating the MICs of tetracycline, doxycycline, and minocycline to the presence of these genes suggest a crossresistance between doxycycline and tetracycline in all strains of $S$. aureus whereas minocycline could be in few cases spared. Caution is therefore recommended in the use of tetracyclines, given its ability to induce resistance in areas in which strains carry the inducible resistance genes (Schwartz et al., 2009). Besides, long-term use of tetracyclines in veterinary medicine has been associated with resistance emergence in commensal Escherichia coli in veal calves (Bosman et al., 2014).

\section{CHLORAMPHENICOL}

Chloramphenicol, the active compound of which is produced by Streptomyces venezuelae, inhibits protein synthesis by binding reversibly to the $50 \mathrm{~S}$ subunit of the bacterial ribosome. It is metabolized primarily in the liver. Dose adjustment is thus required in patients with hepatic insufficiency. Furthermore, chloramphenicol has good oral bioavailability and excellent tissue penetration. Its spectrum of activity is broad, including Gram-positive and Gram-negative bacteria, anaerobes, spirochetes, rickettsiae, chlamydiae, and mycoplasma. But, soon after chloramphenicol was released in the United States in 1949, reports linked this drug to rare but potentially lethal hematological side effects that restricted its use as last-resort therapy. However, as it is readily available and inexpensive, it is still used in many resource-limited settings (Falagas and Kopterides, 2007). Further studies are needed to update its toxicity risk with more accurate dosing and monitoring (Lautenbach et al., 1998).

Chloramphenicol was found to be effective against vancomycin-resistant Enterococcus faecium (VREf), with bacteriostatic activity (Norris et al., 1995). A retrospective analysis of the outcomes of six patients with bacteremia caused by VRE $f$ also showed that this agent was effective (Ricaurte et al., 2001). Several anecdotic reports of effective treatment with chloramphenicol in MDR bacterial severe infections been reported (Table 2 ).

Of $697 \mathrm{VRE}$ samples from 28 US medical centers, only $2.4 \%$ were resistant to chloramphenicol (Zhanel et al., 2003). A significant decrease in rates of resistance to chloramphenicol among isolates of enterococci was reported from 2006 to 2009 in a Brazilian monocentric survey (Conceição et al., 2011). According to the SENTRY Antimicrobial Surveillance Program, the rate of chloramphenicol resistance among E. faecalis is greater in North America than in Europe (28.6 vs. 7.1\%, respectively), but the reverse is true of E. faecium ( 0.5 and $15 \%$, the latter due to clonal occurrences) (Deshpande et al., 2007). Chloramphenicol use for the treatment of VRE infections should take into account the potential for the development of resistance (Lautenbach et al., 2004). Indeed, high levels of resistance likely due to the widespread and unregulated use in resource-limited settings have been reported, particularly for the treatment of severe disease caused by MDR Salmonella sp. or VREf. Most resistance mechanisms are efflux pumps such as floR and $c m l A$, as well as inactivating enzymes such as chloramphenicol acetyl-transferase cat1 (Frye and Jackson, 2013). Furthermore, the association between fluoroquinolone use and 
chloramphenicol-resistant VRE emergence is of concern, since fluoroquinolone use has dramatically increased in recent years (Gould et al., 2004).

\section{CLINDAMYCIN}

Clindamycin is produced by chemical modification of lincomycin, which was isolated in 1962 from Streptomyces lincolnensis (McGehee et al., 1968). This drug works by binding to the $50 \mathrm{~S}$ ribosomal subunit of rRNA and inhibiting the initiation of peptide-chain synthesis. Although concern about Clostridium difficile colitis has limited the use of clindamycin, it remains an important antibiotic in the treatment of severe anaerobic infections.

The main advantage of clindamycin is its potential antiexotoxin activity in necrotizing Panton-Valentin leucocidin (PVL)-positive CA-MRSA-complicated pneumonia or SSTIs, and it is usually used with another anti-MRSA antibiotic (Hidron et al., 2009). Clindamycin is also recommended by clinical practice guidelines as monotherapy for CA-MRSA SSTIs (Stevens et al., 2014).

Among 320 isolates of MRSA (97\% of USA300 strain) from outpatients with SSTIs, 95\% were susceptible to clindamycin (Moran et al., 2006). In another study, 98\% of CA-MRSA isolates from patients with SSTI, were susceptible to clindamycin (Ruhe et al., 2007). Conversely, in Taiwan, a recent study found that nearly $96 \%$ of MRSA isolates from patients with necrotizing fasciitis were resistant to clindamycin. In a recent microbiological survey of CA-MRSA, 72 isolates (85\% of European ST80 clone) from children with severe infections in Greece, clindamycin resistance increased significantly from $0 \%$ (2003) to $31.2 \%$ (2009) among the CA-MRSA isolates (Katopodis et al., 2010).This increase suggests clonal diversity in clindamycin susceptibility among MRSA strains that calls for direct surveillance and reports (Changchien et al., 2011). Moreover, inducible clindamycin resistance should be ruled out by a D-test because a substantial proportion of erythromycin-resistant isolates have shown clindamycin resistance despite appearing susceptible on initial testing (Siberry et al., 2003). Indeed, resistance genes confer resistance to macrolides, lincosamides, streptogramins (MLS). They cause resistance mainly by (i) target site modification, (ii) efflux pumps, and (iii) enzymatic inactivation. But new conjugative transposons (mobile genetic elements) carrying MLS genes along with other antibiotic resistance genes have recently been identified favoring the horizontal spread of resistance (Roberts, 2008). Thus, clindamycin should be used in combination with another anti-staphylococcal antibiotic as empiric therapy in patients with suspected severe staphylococcal infections.

\section{PRISTINAMYCIN}

Pristinamycin, derived from Streptomyces pristinaespiralis, is an oral streptogramin antibiotic made up of two synergistic but structurally unrelated components, pristinamycin IA and pristinamycin IIA. It was discovered over 50 years ago (Cooper et al., 2014).

Although the data are limited, pristinamycin is a well-tolerated and effective alternative for the treatment of BJI due to Grampositive bacteria including MRSA and VRE (Dancer et al., 2003;
Ng and Gosbell, 2005; Ruparelia et al., 2008; Reid et al., 2010). The extended use of pristinamycin for BJI and other infections requires further evaluation.

Many enterococcal species, including those that are vancomycin-resistant though not including Enterococcus faecalis, are also susceptible to pristinamycin (Collins et al., 1993). In France, resistance to pristinamycin has remained low over the last 40 years, and typical susceptibility rates amongst staphylococci are 98\% in the community (Quentin et al., 2001) and $93 \%$ in hospitals (Leclercq et al., 2003). But, also concerned by MLS resistance genes, the use of pristinamycin could favor the horizontal spread of resistance.

\section{RIFAMPICIN}

Rifampicin is a semi synthetic compound derived from Streptomyces mediterranei. It was introduced in 1967 as major part of the anti-tuberculous treatment. Rifampicin has an excellent tissue penetration and a unique activity on bacteria in biofilms growing on the surface of prosthetic devices. Despite the excellent bactericidal activity and oral bioavailability, the rapid emergence of resistance in bacteria constitutes a major limitation and therefore rifampicin should be used in combination with other antimicrobial agents. The cause of rifampicin-resistant mutations within bacteria are due to alteration in the $r p o B$ gene (Forrest and Tamura, 2010).

Despite the lack of a control group and the limited number of patients, colistin and rifampicin appeared to be an effective and safe combination therapy for severe infections caused by MDR Acinetobacter baumanii (Motaouakkil et al., 2006; Bassetti et al., 2008) or MDR Pseudomonas aeruginosa (Tascini et al., 2006). Rifampicin with fusidic acid or rifampicin with fluoroquinolones treatment has been shown to be effective, in combination with surgical debridement, on early prosthesis joint infections (PJI) caused by MRSA (Aboltins et al., 2007). But combination therapy with rifampicin for the treatment of severe MRSA infections needs further studies (Forrest and Tamura, 2010).

\section{FUSIDIC ACID (FA)}

Fusidic acid, which is derived from the fungus Fusidium coccineum, was introduced into clinical practice in 1962 (Godtfredsen et al., 1962). It inhibits polypeptide-chain elongation by binding to the ribosome elongation factor G (EF-G)-GDP complex. FA has excellent oral bioavailability and is metabolized and excreted by the liver. The action of FA is mainly bacteriostatic against Gram-positive bacteria, but this drug has bactericidal activity at higher concentrations. Notably, FA has only limited activity against streptococci and enterococci. It is highly proteinbound and has been shown to have good concentrations in soft tissue, bone and synovial fluid (Turnidge, 1999).

Although there have been no randomized controlled trials of FA as a treatment for BJIs due to MRSA, several case series have reported its effectiveness, mostly in combination with another oral antibiotic (Drancourt et al., 1997; Aboltins et al., 2007; Ferry et al., 2010).

Rates of resistance to FA are higher among coagulase-negative staphylococci (CoNS) than among S. aureus isolates (Pfaller et al., 2010). Although the rate of in vitro resistance to FA among 
S. aureus is less than $10 \%$ in most countries (Wang et al., 2012), there is also a significant trend toward increased FA resistance associated with its increased use (Castanheira et al., 2010). For instance, in Kuwait, the rate of FA resistance increased dramatically from $22 \%$ in 1994 to $92 \%$ in 2004 (Udo et al., 2006). High usage of topical fusidic acid has been associated with clonal spread of fusidic acid-resistant Staphylococcus aureus (Williamson et al., 2014). Key resistance determinants include mutations in the fusA gene, which encodes EF-G, and plasmid-mediated resistance (i.e., acquisition of resistance gene fusB) (Howden and Grayson, 2006). Therefore, this agent must be used in combination with rifampin or other agents to prevent the emergence of resistance.

\section{FORGOTTEN ANTIBIOTICS FOR MULTIDRUG-RESISTANT M. TUBERCULOSIS}

Tuberculosis strains classified as MDR are those resistant to at least the two most potent first-line antituberculosis drugs (i.e., isoniazid and rifampicin) (Caminero et al., 2006). Extensively drug-resistant (XDR) tuberculosis (TB) strains are resistant to isoniazid or rifampicin (like MDR-TB), any fluoroquinolone, and at least one of three second-line injectable antituberculosis drugs (i.e., capreomycin, kanamycin, and amikacin) (Caminero et al., 2010). MDR and XDR-TB are generally thought to have high mortality rates. Treatment is challenging because of the high toxicity of second-line drugs and the longer treatment duration that participates to reduce the choice of available therapy. In a recent series of patients with XDR-TB, 58\% experienced drug-associated adverse events including 9\% lethal; therapy was discontinued in $28 \%$ (Shean et al., 2013). Right combination and rational use of available and safe antituberculosis drugs is therefore challenging (Mitnick et al., 2008). However, standardized strategies including pretreatment counseling, and follow-up are essential prerequisites in view to optimize therapy.

Here, we evaluated the clinical efficacy of 2 drugs belonging to group five in the World Health Organization (WHO) guidelines on MDR-TB treatment (i.e., clofazimine and amoxicillinie with clavulanate) and 2 antibiotics that are not listed but that may be candidates for evaluation against Mycobacterium tuberculosis (i.e., TMP/SMX and minocycline).

\section{CLOFAZIMINE}

Clofazimine, a lipophilic riminophenazine antibiotic, was first synthesized in 1954 by Barry et al. as an anti-tuberculosis drug (Barry et al., 1957) but has known extended clinical use in the early 1970s to fight the emergence of Mycobacterium leprae resistant to sulfones.

In a report from Bangladesh, regimens containing clofazimine showed high efficacy ( $87.9 \%$ cure rate) in the treatment of MDRTB (Van Deun et al., 2010). In a Korean study, 32 patients with MDR-TB and additional resistance to ofloxacin (11 with XDRTB) were treated with clofazimine-containing regimens, with a lower cure rate (48.4\%) (Yoo et al., 2013). Another recent report showed a cure rate of $38.4 \%$ with combination regimens including clofazimine for the treatment of MDR-TB, with mild adverse events (Xu et al., 2012). Adequate dose management would help to control adverse events, especially photosensitivity and gastric intolerance. Clofazimine's low cost is an additional advantage, although the drug is not widely available (Caminero et al., 2010).

\section{AMOXICILLIN WITH CLAVULANATE}

Amoxicilline-clavulanate, combined with other second-line drugs, has been successfully used to treat patients with

Table 3 | Availability from usual marketing system of the selected antibiotics in Europe, the USA, Canada and Australia (adapted from Pulcini et al., 2012).

\begin{tabular}{ll}
\hline Molecules & Countries \\
\hline Colistin & AT, AU, BG, CA, CH, CZ, DK, EL, ES, FI, FR, FY, HU, IE, IT, LU, LV, MT, PL, PT, RO, SK, TR, UK, US \\
Fosfomycin IV & AT, DE, EL, ES, FR, IT \\
Fosfomycin PO & AT, BE, BG, CA, CH, DE, ES, FR, IE, IT, LU, NL, PL, PT, RO, SK, TR, US \\
Mecillinam & $\mathrm{DK}, \mathrm{EL}$ \\
Pivmecillinam & $\mathrm{AT}, \mathrm{CA}, \mathrm{DK}, \mathrm{Fl}, \mathrm{FR}, \mathrm{IS}, \mathrm{NO}, \mathrm{PT}, \mathrm{SE}, \mathrm{UK}, \mathrm{ES}, \mathrm{LU}$ \\
Temocillin & $\mathrm{BE}, \mathrm{UK}$ \\
Nitrofurantoin & $\mathrm{AL}, \mathrm{AT}, \mathrm{AU}, \mathrm{BE}, \mathrm{BG}, \mathrm{CA}, \mathrm{CH}, \mathrm{DE}, \mathrm{DK}, \mathrm{EE}, \mathrm{EL}, \mathrm{ES}, \mathrm{FI}, \mathrm{FR}, \mathrm{HR}, \mathrm{HU}, \mathrm{IE}, \mathrm{IS}, \mathrm{IT}, \mathrm{LT}, \mathrm{LU}, \mathrm{LV}, \mathrm{MT}, \mathrm{NL}, \mathrm{NO}, \mathrm{PL}, \mathrm{PT}, \mathrm{RO}, \mathrm{TR}, \mathrm{UK}$, \\
& $\mathrm{US}, \mathrm{XZ}$ \\
Trimethoprim-sulfamethoxazole & $\mathrm{AT}, \mathrm{AU}, \mathrm{BE}, \mathrm{CH}, \mathrm{CZ}, \mathrm{DE}, \mathrm{DK}, \mathrm{EL}, \mathrm{ES}, \mathrm{FI}, \mathrm{FR}, \mathrm{HU}, \mathrm{IE}, \mathrm{IT}, \mathrm{LU}, \mathrm{NL}, \mathrm{NO}, \mathrm{PL}, \mathrm{PT}, \mathrm{RO}, \mathrm{SE}, \mathrm{SK}, \mathrm{UK}, \mathrm{US}$ \\
Doxycycline & $\mathrm{AT}, \mathrm{AU}, \mathrm{BE}, \mathrm{CH}, \mathrm{CZ}, \mathrm{DE}, \mathrm{DK}, \mathrm{EL}, \mathrm{ES}, \mathrm{FI}, \mathrm{FR}, \mathrm{HU}, \mathrm{IE}, \mathrm{IT}, \mathrm{LU}, \mathrm{NL}, \mathrm{NO}, \mathrm{PL}, \mathrm{PT}, \mathrm{RO}, \mathrm{SE}, \mathrm{SK}, \mathrm{UK}, \mathrm{US}$ \\
Minocycline & $\mathrm{AT}, \mathrm{AU}, \mathrm{BE}, \mathrm{CH}, \mathrm{CZ}, \mathrm{DE}, \mathrm{EL}, \mathrm{ES}, \mathrm{FR}, \mathrm{IE}, \mathrm{IT}, \mathrm{LU}, \mathrm{NL}, \mathrm{PT}, \mathrm{RO}, \mathrm{SE}, \mathrm{UK}, \mathrm{US}$ \\
Chloramphenicol & $\mathrm{AL}, \mathrm{BG}, \mathrm{CA}, \mathrm{CZ}, \mathrm{EL}, \mathrm{ES}, \mathrm{FI}, \mathrm{IS}, \mathrm{IT}, \mathrm{MT}, \mathrm{NO}, \mathrm{PT}, \mathrm{RS}, \mathrm{SE}, \mathrm{SK}, \mathrm{TR}, \mathrm{UK}, \mathrm{US}, \mathrm{XZ}$ \\
Clindamycin & $\mathrm{AT}, \mathrm{AU}, \mathrm{CH}, \mathrm{DE}, \mathrm{DK}, \mathrm{EL}, \mathrm{ES}, \mathrm{FI}, \mathrm{FR}, \mathrm{HU}, \mathrm{IE}, \mathrm{IT}, \mathrm{LU}, \mathrm{NL}, \mathrm{NO}, \mathrm{PL}, \mathrm{PT}, \mathrm{RO}, \mathrm{SE}, \mathrm{SK}, \mathrm{UK}, \mathrm{US}$ \\
Pristinamycin & $\mathrm{FR}, \mathrm{LU}$ \\
Clofazimine & $\mathrm{AU}, \mathrm{CH}, \mathrm{CZ}, \mathrm{EL}, \mathrm{ES}, \mathrm{IE}, \mathrm{FR}, \mathrm{NL}, \mathrm{US}, \mathrm{UK}$ \\
\hline
\end{tabular}

AL, Albania; AT, Austria; AU, Australia; BE, Belgium; BG, Bulgaria; CA, Canada; CH, Switzerland; CZ, Czech Republic; DE, Germany; DK, Denmark; EE, Estonia; EL, Greece; ES, Spain; FI, Finland; FR, France; FY, Republic of Macedonia; HR, Croatia; HU, Hungary; IE, Ireland; IS, Iceland; IT, Italy; LT, Lithuania; LU, Luxembourg; LV,

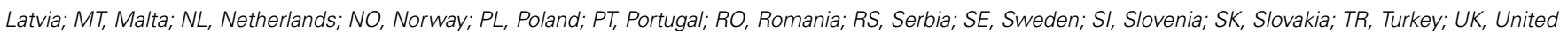
Kingdom; US, United States; XZ, Kosovo; IV, Intra-venous; PO, Per os. 
MDR-tuberculosis (Nadler et al., 1991; Mitnick et al., 2008). The good tolerability, low price, and low toxicity profile of this drug have made it the drug of choice within group five according to the WHO guidelines for MDR-TB treatment (Caminero et al., 2006).

\section{TRIMETHOPRIM-SULFAMETHOXAZOLE (TMP/SMX)}

Between the late 1930s and the early 1950s, sulfonamides were used, usually as a monotherapy, for the treatment of tuberculosis. Because of the toxicity of the early sulfonamides and the introduction of highly effective anti-tuberculosis drugs such as isoniazid and streptomycin, both groups of drugs were abandoned for the treatment of tuberculosis in the early 1950s, and their use was essentially forgotten (Forgacs et al., 2009).

Clinical experience with TMP/SMX is scarce, but there is promising evidence supporting the treatment of XDR-TB with combination regimens (Forgacs et al., 2009; Dubourg et al., 2013). In light of those results and the fact that MDR and XDR M. tuberculosis strains have been found to be susceptible in vitro to both sulfadiazine and TMP/SMX (Ameen and Drancourt, 2013), further clinical trials are needed to consider sulfamides as alternative anti-tuberculosis antibiotics in combination regimens.

The great susceptibility of M. tuberculosis to TMP/SMX has been recently confirmed and attributed to the sulfonamide compound alone (Huang et al., 2012). In this study, susceptibility to sulfamethoxazole remained constant over a 12 -year period despite the expanded use of TMP/SMX in the HIV-positive population.

\section{MINOCYCLINE}

Minocycline activity against $M$. tuberculosis was first reported in 1983 (Tsukamura et al., 1983). This molecule is effective against $M$. leprae and has been used in combination regimens for the treatment of leprosy; however, minocycline was successfully used in the rescue treatment of an XDR-TB patient in Japan (Kawada et al., 2008). More recently, Brouqui et al. reported the first effective treatment with a regimen including linezolid, minocycline, sulfadiazine, and clofazimine according to the susceptibility profile of a patient with XDR-TB (Brouqui et al., 2013).

\section{CONCLUSION}

In an era of increasing emergence of drug resistance and a scarcity of new antibiotics, there is a growing need to optimize the use of old and new antibiotics to treat infections. The arsenal of available antimicrobial drugs may be regulated by principles other than the lack of profit for drugs in limited-market areas. Indeed, in the last 20 years, pharmaceutical companies have developed highly profitable drugs that treat chronic diseases (i.e., hypertension, diabetes, dyslipidemia, and psychiatric disorders) rather than new antibiotics (Spellberg et al., 2004). Most likely for the same reasons, small countries have undergone shortages and market withdrawals of older antibiotics (Pulcini et al., 2012). Despite the increasing evidence of their effectiveness and safety, the United States Food and Drug Administration (FDA) has still not approved the use of some old antibiotics (i.e., fusidic acid, intravenous fosfomycin, pivmecillinam, temocillin, pristinamycin) (Table 3) http://www.accessdata.fda.gov/scripts/cder/ drugsatfda/. As public health concern, cost effectiveness might be integrated in further comparisons between old and currently used antibiotics.

Optimization of antibiotic therapy in terms of pharmacokinetics and pharmacodynamics is needed to improve therapeutic outcomes but minimize the toxicity and the risk of resistance emerging during treatment (Mouton et al., 2011). Indeed, subtherapeutic concentrations may favor the development of resistance in both the infecting pathogen and the commensal flora (Mohamed et al., 2012). Moreover, dosage adjustments, avoidance of co-administration of other toxic agents, and prompt discontinuation after early signs of toxicity are critical for the clinical revaluation of old antibiotics. For instance, recent studies revealed that adverse events with colistin were not as frequent as previously reported, in part due to more accurate prescription (Falagas and Kasiakou, 2006). Updates of old antibiotics toxicity assessment with optimized dosing and monitoring and adapted pharmacological studies are urgently warranted.

Finally, as old antibiotics are rarely included in surveillance programs, data regarding resistance rates, minimal inhibitory concentration (MIC), and harmonization are lacking (Mouton et al., 2011). Moreover, geographic variations make the extrapolation of local results inaccurate (Deshpande et al., 2007). Thus, susceptibility testing for old but effective and safe antibiotics may be integrated into routine practice in the way to ensure antimicrobial resistance local surveillance. As some of these old antibiotics (i.e., fosfomycin, TMP/SMX, clindamycin, pristinamycin, and fusidic acid) could also favor horizontal spread of resistance, their reuse should be associated with a global ecology survey. In this case, combination therapy remains an alternative for their reuse.

In summary, all old antibiotics included in this review have been associated with successful treatment of MDR bacterial infections. Their reuse represents a promising strategy to fight antimicrobial resistance. But some points remain critical for their revival in a sustainable manner and need further evaluations. First, clinical trials comparing the clinical, safety, and cost effectiveness with current antibiotics are lacking. Second, prescription of old antibiotics needs also to be regulated by antibiotic stewardships and guided by resistance rates monitoring. Third, optimization of the usage of old antibiotics remains a priority that may be considered of similar importance to that of the assessment of new drugs.

\section{AUTHOR CONTRIBUTIONS}

Nadim Cassir wrote the paper. Jean-Marc Rolain and Philippe Brouqui reviewed and edited the paper for content and accuracy.

\section{REFERENCES}

Aboltins, C. A., Page, M. A., Buising, K. L., Jenney, A. W. J., Daffy, J. R., Choong, P. F. M., et al. (2007). Treatment of staphylococcal prosthetic joint infections with debridement, prosthesis retention and oral rifampicin and fusidic acid. Clin. Microbiol. Infect. 13, 586-591. doi: 10.1111/j.1469-0691.2007.01691.x

Adams-Haduch, J. M., Potoski, B. A., Sidjabat, H. E., Paterson, D. L., and Doi, Y. (2009). Activity of temocillin against KPC-producing Klebsiella pneumoniae and Escherichia coli. Antimicrob. Agents Chemother. 53, 2700-2701. doi: 10.1128/AAC.00290-09

Adra, M., and Lawrence, K. R. (2004). Trimethoprim/sulfamethoxazole for treatment of severe Staphylococcus aureus infections. Ann. Pharmacother. 38, 338-341. doi: 10.1345/aph.1D156

Ahamed Puthiyaveetil, S. (2009). Osteomyelitis-a case report. Aust. Fam. Physician $38,521-523$. 
Ameen, S. M., and Drancourt, M. (2013). In vitro susceptibility of Mycobacterium tuberculosis to trimethoprim and sulfonamides in France. Antimicrob. Agents Chemother. 57, 6370-6371. doi: 10.1128/AAC.01683-13

American Thoracic Society, and Infectious Diseases Society of America. (2005). Guidelines for the management of adults with hospital-acquired, ventilatorassociated, and healthcare-associated pneumonia. Am. J. Respir. Crit. Care Med. 171, 388-416. doi: 10.1164/rccm.200405-644ST

Andersson, D. I., and Hughes, D. (2010). Antibiotic resistance and its cost: is it possible to reverse resistance? Nat. Rev. Microbiol. 8, 260-271. doi: 10.1038/nrmicro2319

Apisarnthanarak, A., and Mundy, L. M. (2012). Carbapenem-resistant Pseudomonas aeruginosa pneumonia with intermediate minimum inhibitory concentrations to doripenem: combination therapy with high-dose, 4-h infusion of doripenem plus fosfomycin versus intravenous colistin plus fosfomycin. Int. J. Antimicrob. Agents 39, 271-272. doi: 10.1016/j.ijantimicag.2011. 11.012

Balakrishnan, I., Awad-El-Kariem, F. M., Aali, A., Kumari, P., Mulla, R., Tan, B., et al. (2011). Temocillin use in England: clinical and microbiological efficacies in infections caused by extended-spectrum and/or derepressed AmpC $\beta$-lactamase-producing Enterobacteriaceae. J. Antimicrob. Chemother. 66, 2628-2631. doi: 10.1093/jac/dkr317

Barry, V. C., Belton, J. G., Conalty, M. L., Denneny, J. M., Edward, D. W., O’Sullivan, J. F., et al. (1957). A new series of phenazines (rimino-compounds) with high antituberculosis activity. Nature 179, 1013-1015.

Barton, E., Flanagan, P., and Hill, S. (2008). Spinal infection caused by ESBLproducing Klebsiella pneumoniae treated with temocillin. J. Infect. 57, 347-349. doi: 10.1016/j.jinf.2008.08.001

Bassetti, M., Repetto, E., Righi, E., Boni, S., Diverio, M., Molinari, M. P., et al. (2008). Colistin and rifampicin in the treatment of multidrug-resistant Acinetobacter baumannii infections. J. Antimicrob. Chemother. 61, 417-420. doi: $10.1093 / \mathrm{jac} / \mathrm{dkm} 509$

Bengtsson, E., Svanbom, M., and Tunevall, G. (1974). Trimethoprimsulphamethoxazole treatment in staphylococcal endocarditis and gram-negative septicemia. Scand. J. Infect. Dis. 6, 177-182.

Betrosian, A. P., Frantzeskaki, F., Xanthaki, A., and Douzinas, E. E. (2008). Efficacy and safety of high-dose ampicillin/sulbactam vs. colistin as monotherapy for the treatment of multidrug resistant Acinetobacter baumannii ventilator-associated pneumonia. J. Infect. 56, 432-436. doi: 10.1016/j.jinf.2008.04.002

Biswas, S., Brunel, J.-M., Dubus, J.-C., Reynaud-Gaubert, M., and Rolain, J.-M. (2012). Colistin: an update on the antibiotic of the 21st century. Expert Rev. Anti Infect. Ther. 10, 917-934. doi: 10.1586/eri.12.78

Bosman, A. B., Wagenaar, J. A., Stegeman, J. A., Vernooij, J. C. M., and Mevius, D. J. (2014). Antimicrobial resistance in commensal Escherichia coli in veal calves is associated with antimicrobial drug use. Epidemiol. Infect. 142, 1893-1904. doi: 10.1017/S0950268813002665

Brouqui, P., Aubry, C., Million, M., Drancourt, M., and Raoult, D. (2013). Totally resistant tuberculosis: will antileprosy drugs be helpful? Int. J. Antimicrob. Agents 42, 584-585. doi: 10.1016/j.ijantimicag.2013.08.004

Cadena, J., Nair, S., Henao-Martinez, A. F., Jorgensen, J. H., Patterson, J. E., and Sreeramoju, P. V. (2011). Dose of trimethoprim-sulfamethoxazole to treat skin and skin structure infections caused by methicillin-resistant Staphylococcus aureus. Antimicrob. Agents Chemother. 55, 5430-5432. doi: 10.1128/AAC. 00706-11

Cai, Y., Chai, D., Wang, R., Liang, B., and Bai, N. (2012). Colistin resistance of Acinetobacter baumannii: clinical reports, mechanisms and antimicrobial strategies. J. Antimicrob. Chemother. 67, 1607-1615. doi: 10.1093/jac/dks084

Caminero, J. A., Sotgiu, G., Zumla, A., and Migliori, G. B. (2010). Best drug treatment for multidrug-resistant and extensively drug-resistant tuberculosis. Lancet Infect. Dis. 10, 621-629. doi: 10.1016/S1473-3099(10)70139-0

Caminero, J. A., World Health Organization, American Thoracic Society, and British Thoracic Society. (2006). Treatment of multidrug-resistant tuberculosis: evidence and controversies. Int. J. Tuberc. Lung Dis. 10, 829-837.

Campbell, M. L., Marchaim, D., Pogue, J. M., Sunkara, B., Bheemreddy, S., Bathina, P., et al. (2012). Treatment of methicillin-resistant Staphylococcus aureus infections with a minimal inhibitory concentration of $2 \mu \mathrm{g} / \mathrm{mL}$ to vancomycin: old (trimethoprim/sulfamethoxazole) versus new (daptomycin or linezolid) agents. Ann. Pharmacother. 46, 1587-1597. doi: 10.1345/aph.1R211

Casalta, J.-P., Zaratzian, C., Hubert, S., Thuny, F., Gouriet, F., Habib, G., et al. (2013). Treatment of Staphylococcus aureus endocarditis with high doses of trimethoprim/sulfamethoxazole and clindamycin-preliminary report. Int. J. Antimicrob. Agents 42, 190-191. doi: 10.1016/j.ijantimicag.2013.05.002

Castanheira, M., Watters, A. A., Mendes, R. E., Farrell, D. J., and Jones, R. N. (2010). Occurrence and molecular characterization of fusidic acid resistance mechanisms among Staphylococcus spp. from European countries (2008). J. Antimicrob. Chemother. 65, 1353-1358. doi: 10.1093/jac/dkq094

Cenizal, M. J., Skiest, D., Luber, S., Bedimo, R., Davis, P., Fox, P., et al. (2007). Prospective randomized trial of empiric therapy with trimethoprim-sulfamethoxazole or doxycycline for outpatient skin and soft tissue infections in an area of high prevalence of methicillin-resistant Staphylococcus aureus. Antimicrob. Agents Chemother. 51, 2628-2630. doi: 10. 1128/AAC.00206-07

Changchien, C.-H., Chen, Y.-Y., Chen, S.-W., Chen, W.-L., Tsay, J.-G., and Chu, C. (2011). Retrospective study of necrotizing fasciitis and characterization of its associated Methicillin-resistant Staphylococcus aureus in Taiwan. BMC Infect. Dis. 11:297. doi: 10.1186/1471-2334-11-297

Chen, A. E., Goldstein, M., Carroll, K., Song, X., Perl, T. M., and Siberry, G. K. (2006). Evolving epidemiology of pediatric Staphylococcus aureus cutaneous infections in a Baltimore hospital. Pediatr. Emerg. Care 22, 717-723. doi: 10. 1097/01.pec.0000236832.23947.a0

Chiang, E.-R., Su, Y.-P., Chen, T.-H., Chiu, F.-Y., and Chen, W.-M. (2011). Comparison of articulating and static spacers regarding infection with resistant organisms in total knee arthroplasty. Acta Orthop. 82, 460-464. doi: 10.3109/ 17453674.2011 .581266

Clumeck, N., Marcelis, L., Amiri-Lamraski, M. H., and Gordts, B. (1984) Treatment of severe staphylococcal infections with a rifampicin-minocycline association. J. Antimicrob. Chemother. 13 Suppl C:17-22. doi: 10.1093/jac/13. suppl_C.17

Collins, L. A., Malanoski, G. J., Eliopoulos, G. M., Wennersten, C. B., Ferraro, M. J. and Moellering, R. C. (1993). In vitro activity of RP59500, an injectable streptogramin antibiotic, against vancomycin-resistant gram-positive organisms. Antimicrob. Agents Chemother. 37, 598-601. doi: 10.1128/AAC.37.3.598

Conceição, N., de Oliveira, C. C. H. B., da Silva, P. R., Avila, B. G. M., and de Oliveira, A. G. (2011). Trends in antimicrobial resistance among clinical isolates of enterococci in a Brazilian tertiary hospital: a 4-year study. Rev. Soc. Bras. Med. Trop. 44, 177-181. doi: 10.1590/S0037-86822011005000009

Cooper, E. C., Curtis, N., Cranswick, N., and Gwee, A. (2014). Pristinamycin: old drug, new tricks? J. Antimicrob. Chemother. 69, 2319-2325. doi: 10.1093/jac/dku167

Cunha, B. A. (1989). Nitrofurantoin: an update. Obstet. Gynecol. Surv. 44, 399-406 doi: 10.1097/00006254-198905000-00034

Cunha, B. A. (2013). Minocycline, often forgotten but preferred to trimethoprimsulfamethoxazole or doxycycline for the treatment of community-acquired meticillin-resistant Staphylococcus aureus skin and soft-tissue infections. Int. J. Antimicrob. Agents 42, 497-499. doi: 10.1016/j.ijantimicag.2013. 08.006

Cunha, B. A., Schoch, P. E., and Hage, J. R. (2011). Nitrofurantoin: preferred empiric therapy for community-acquired lower urinary tract infections. Mayo Clin. Proc. 86, 1243-1244. author reply: 1244. doi: 10.4065/mcp.2011.0411

Dancer, S. J., Robb, A., Crawford, A., and Morrison, D. (2003). Oral streptogramins in the management of patients with methicillin-resistant Staphylococcus aureus (MRSA) infections. J. Antimicrob. Chemother. 51, 731-735. doi: $10.1093 / \mathrm{jac} / \mathrm{dkg} 143$

D’Costa, V. M., King, C. E., Kalan, L., Morar, M., Sung, W. W. L., Schwarz, C., et al. (2011). Antibiotic resistance is ancient. Nature 477, 457-461. doi: 10.1038/ nature 10388

De Boutin, J. L., Manuel, C., Charrel, J., Aubert, C., Mallet, M. N., Gevaudan, M. J., et al. (1985). [Value of the aminoglycoside-fosfomycin combination. Apropos of a case of bacterial endocarditis]. Pathol. Biol. 33, 684-686.

de Górgolas, M., Avilés, P., Verdejo, C., and Fernández Guerrero, M. L. (1995). Treatment of experimental endocarditis due to methicillinsusceptible or methicillin-resistant Staphylococcus aureus with trimethoprimsulfamethoxazole and antibiotics that inhibit cell wall synthesis. Antimicrob. Agents Chemother. 39, 953-957. doi: 10.1128/AAC.39.4.953

De Jongh, R., Hens, R., Basma, V., Mouton, J. W., Tulkens, P. M., and Carryn, S. (2008). Continuous versus intermittent infusion of temocillin, a directed spectrum penicillin for intensive care patients with nosocomial pneumonia: stability, compatibility, population pharmacokinetic studies and breakpoint selection. J. Antimicrob. Chemother. 61, 382-388. doi: 10.1093/jac/dkm467 
Demers, P., Fraser, D., Goldbloom, R. B., Haworth, J. C., LaRochelle, J., MacLean, R., et al. (1968). Effects of tetracyclines on skeletal growth and dentition. A report by the Nutrition Committee of the Canadian Paediatric Society. Can. Med. Assoc. J. 99, 849-854.

Deshpande, L. M., Fritsche, T. R., Moet, G. J., Biedenbach, D. J., and Jones, R. N. (2007). Antimicrobial resistance and molecular epidemiology of vancomycinresistant enterococci from North America and Europe: a report from the SENTRY antimicrobial surveillance program. Diagn. Microbiol. Infect. Dis. 58, 163-170. doi: 10.1016/j.diagmicrobio.2006.12.022

Dewar, S., Reed, L. C., and Koerner, R. J. (2014). Emerging clinical role of pivmecillinam in the treatment of urinary tract infection in the context of multidrug-resistant bacteria. J. Antimicrob. Chemother. 69, 303-308. doi: $10.1093 / \mathrm{jac} / \mathrm{dkt} 368$

Di Carlo, P., D’Alessandro, N., Guadagnino, G., Bonura, C., Mammina, C., Lunetta, M., et al. (2013). High dose of trimethoprim-sulfamethoxazole and daptomycin as a therapeutic option for MRSA endocarditis with large vegetation complicated by embolic stroke: a case report and literature review. Infez. Med. 21, 45-49.

Diene, S. M., Merhej, V., Henry, M., El Filali, A., Roux, V., Robert, C., et al. (2013). The rhizome of the multidrug-resistant Enterobacter aerogenes genome reveals how new "killer bugs" are created because of a sympatric lifestyle. Mol. Biol. Evol. 30, 369-383. doi: 10.1093/molbev/mss236

Diep, B. A., Chambers, H. F., Graber, C. J., Szumowski, J. D., Miller, L. G., Han, L. L., et al. (2008). Emergence of multidrug-resistant, community-associated, methicillin-resistant Staphylococcus aureus clone USA300 in men who have sex with men. Ann. Intern. Med. 148, 249-257. doi: 10.7326/0003-4819-148-4200802190-00204

Dinh, A., Salomon, J., Bru, J. P., and Bernard, L. (2012). Fosfomycin: efficacy against infections caused by multidrug-resistant bacteria. Scand. J. Infect. Dis. 44, 182-189. doi: 10.3109/00365548.2011.616221

Drancourt, M., Stein, A., Argenson, J. N., Roiron, R., Groulier, P., and Raoult, D. (1997). Oral treatment of Staphylococcus spp. infected orthopaedic implants with fusidic acid or ofloxacin in combination with rifampicin. J. Antimicrob. Chemother. 39, 235-240. doi: 10.1093/jac/39.2.235

Dubourg, G., Lagier, J. C., Armougom, F., Robert, C., Hamad, I., Brouqui, P., et al. (2013). The gut microbiota of a patient with resistant tuberculosis is more comprehensively studied by culturomics than by metagenomics. Eur. J. Clin. Microbiol. Infect. Dis. 32, 637-645. doi: 10.1007/s10096-0121787-3

Duerinckx, J. F. H. (2008). Case Report: subacute synovitis of the knee after a rose thorn injury: unusual clinical picture. Clin. Orthop. Relat. Res. 466, 3138-3142. doi: 10.1007/s11999-008-0482-2

Falagas, M. E., Giannopoulou, K. P., Kokolakis, G. N., and Rafailidis, P. I. (2008). Fosfomycin: use beyond urinary tract and gastrointestinal infections. Clin. Infect. Dis. 46, 1069-1077. doi: 10.1086/527442

Falagas, M. E., and Kasiakou, S. K. (2005). Colistin: the revival of polymyxins for the management of multidrug-resistant gram-negative bacterial infections. Clin. Infect. Dis. 40, 1333-1341. doi: 10.1086/429323

Falagas, M. E., and Kasiakou, S. K. (2006). Toxicity of polymyxins: a systematic review of the evidence from old and recent studies. Crit Care 10, R27. doi: $10.1186 / \mathrm{cc} 3995$

Falagas, M. E., Kasiakou, S. K., Kofteridis, D. P., Roditakis, G., and Samonis, G. (2006a). Effectiveness and nephrotoxicity of intravenous colistin for treatment of patients with infections due to polymyxin-only-susceptible (POS) gram-negative bacteria. Eur. J. Clin. Microbiol. Infect. Dis. 25, 596-599. doi: 10.1007/s10096-006-0191-2

Falagas, M. E., Kastoris, A. C., Karageorgopoulos, D. E., and Rafailidis, P. I. (2009). Fosfomycin for the treatment of infections caused by multidrug-resistant non-fermenting Gram-negative bacilli: a systematic review of microbiological, animal and clinical studies. Int. J. Antimicrob. Agents 34, 111-120. doi: 10.1016/j.ijantimicag.2009.03.009

Falagas, M. E., and Kopterides, P. (2007). Old antibiotics for infections in critically ill patients. Curr. Opin. Crit. Care 13, 592-597. doi: 10.1097/MCC.0b013e32827 $851 \mathrm{~d} 7$

Falagas, M. E., Rafailidis, P. I., Kasiakou, S. K., Hatzopoulou, P., and Michalopoulos, A. (2006b). Effectiveness and nephrotoxicity of colistin monotherapy vs. colistin-meropenem combination therapy for multidrug-resistant Gramnegative bacterial infections. Clin. Microbiol. Infect. 12, 1227-1230. doi: 10.1111/ j.1469-0691.2006.01559.x
Ferry, T., Uçkay, I., Vaudaux, P., François, P., Schrenzel, J., Harbarth, S., et al. (2010). Risk factors for treatment failure in orthopedic device-related methicillinresistant Staphylococcus aureus infection. Eur. J. Clin. Microbiol. Infect. Dis. 29, 171-180. doi: 10.1007/s10096-009-0837-y

Forgacs, P., Wengenack, N. L., Hall, L., Zimmerman, S. K., Silverman, M. L., and Roberts, G. D. (2009). Tuberculosis and trimethoprim-sulfamethoxazole. Antimicrob. Agents Chemother. 53, 4789-4793. doi: 10.1128/AAC.01658-08

Forrest, G. N., and Tamura, K. (2010). Rifampin combination therapy for nonmycobacterial infections. Clin. Microbiol. Rev. 23, 14-34. doi: 10.1128/CMR. 00034-09

Frye, J. G., and Jackson, C. R. (2013). Genetic mechanisms of antimicrobial resistance identified in Salmonella enterica, Escherichia coli, and Enteroccocus spp. isolated from U.S. food animals. Front Microbiol 4:135. doi: 10.3389/fmicb.2013. 00135

Fujino, T., Amari, Y., Mohri, M., Noma, M., and Yamamoto, H. (2009). MRSA tricuspid valve infective endocarditis with multiple embolic lung abscesses treated by combination therapy of vancomycin, rifampicin, and sulfamethoxazole/trimethoprim. J. Cardiol. 53, 146-149. doi: 10.1016/j.jjcc.2008.06.007

Fulnecky, E. J., Wright, D., Scheld, W. M., Kanawati, L., and Shoham, S. (2005) Amikacin and colistin for treatment of Acinetobacter baumannii meningitis. J. Infect. 51, e249-e251. doi: 10.1016/j.jinf.2005.04.003

Garnacho-Montero, J., Ortiz-Leyba, C., Jiménez-Jiménez, F. J., Barrero-Almodóvar, A. E., García-Garmendia, J. L., Bernabeu-Wittel, I. M., et al. (2003). Treatment of multidrug-resistant Acinetobacter baumannii ventilator-associated pneumonia (VAP) with intravenous colistin: a comparison with imipenem-susceptible VAP. Clin. Infect. Dis. 36, 1111-1118. doi: 10.1086/374337

Glupczynski, Y., Huang, T.-D., Berhin, C., Claeys, G., Delmée, M., Ide, L., et al. (2007). In vitro activity of temocillin against prevalent extended-spectrum betalactamases producing Enterobacteriaceae from Belgian intensive care units. Eur. J. Clin. Microbiol. Infect. Dis. 26, 777-783. doi: 10.1007/s10096-007-0370-9

Godtfredsen, W., Roholt, K., and Tybring, L. (1962). Fucidin: a new orally active antibiotic. Lancet 1, 928-931. doi: 10.1016/S0140-6736(62)91968-2

Goldberg, E., Paul, M., Talker, O., Samra, Z., Raskin, M., Hazzan, R., et al. (2010). Co-trimoxazole versus vancomycin for the treatment of methicillin-resistant Staphylococcus aureus bacteraemia: a retrospective cohort study. J. Antimicrob. Chemother. 65, 1779-1783. doi: 10.1093/jac/dkq179

Gould, C. V., Fishman, N. O., Nachamkin, I., and Lautenbach, E. (2004). Chloramphenicol resistance in vancomycin-resistant enterococcal bacteremia: impact of prior fluoroquinolone use? Infect. Control Hosp. Epidemiol. 25, 138-145. doi: 10.1086/502365

Graninger, W. (2003). Pivmecillinam-therapy of choice for lower urinary tract infection. Int. J. Antimicrob. Agents 22(Suppl. 2), 73-78. doi: 10.1016/S09248579(03)00235-8

Grim, S. A., Rapp, R. P., Martin, C. A., and Evans, M. E. (2005). Trimethoprimsulfamethoxazole as a viable treatment option for infections caused by methicillin-resistant Staphylococcus aureus. Pharmacotherapy 25, 253-264. doi: 10.1592/phco.25.2.253.56956

Gupta, K., Hooton, T. M., Naber, K. G., Wullt, B., Colgan, R., Miller, L. G., et al. (2011). International clinical practice guidelines for the treatment of acute uncomplicated cystitis and pyelonephritis in women: A 2010 update by the Infectious Diseases Society of America and the European Society for Microbiology and Infectious Diseases. Clin. Infect. Dis. 52, e103-e120. doi: $10.1093 / \mathrm{cid} / \mathrm{ciq} 257$

Gupta, N. D., Smith, R. E., and Balakrishnan, I. (2009). Clinical efficacy of temocillin. J. Antimicrob. Chemother. 64, 431-433. doi: 10.1093/jac/dkp208

Heintz, B. H., Halilovic, J., and Christensen, C. L. (2010). Vancomycin-resistant enterococcal urinary tract infections. Pharmacotherapy 30, 1136-1149. doi: 10.1592/phco.30.11.1136

Hidron, A. I., Low, C. E., Honig, E. G., and Blumberg, H. M. (2009). Emergence of community-acquired meticillin-resistant Staphylococcus aureus strain USA300 as a cause of necrotising community-onset pneumonia. Lancet Infect. Dis. 9, 384-392. doi: 10.1016/S1473-3099(09)70133-1

Howden, B. P., and Grayson, M. L. (2006). Dumb and dumber-the potential waste of a useful antistaphylococcal agent: emerging fusidic acid resistance in Staphylococcus aureus. Clin. Infect. Dis. 42, 394-400. doi: 10.1086/499365

Huang, T.-S., Kunin, C. M., Yan, B.-S., Chen, Y.-S., Lee, S. S.-J., and Syu, W. (2012). Susceptibility of mycobacterium tuberculosis to sulfamethoxazole, trimethoprim and their combination over a 12 year period in Taiwan. J. Antimicrob. Chemother. 67, 633-637. doi: 10.1093/jac/dkr501 
Jansåker, F., Frimodt-Møller, N., Sjögren, I., and Dahl Knudsen, J. (2014). Clinical and bacteriological effects of pivmecillinam for ESBL-producing Escherichia coli or Klebsiella pneumoniae in urinary tract infections. J. Antimicrob. Chemother. 69, 769-772. doi: 10.1093/jac/dkt404

Jiménez-Mejías, M. E., Pichardo-Guerrero, C., Márquez-Rivas, F. J., MartínLozano, D., Prados, T., and Pachón, J. (2002). Cerebrospinal fluid penetration and pharmacokinetic/pharmacodynamic parameters of intravenously administered colistin in a case of multidrug-resistant Acinetobacter baumannii meningitis. Eur. J. Clin. Microbiol. Infect. Dis. 21, 212-214. doi: 10.1007/s10096001-0680-2

Kallel, H., Hergafi, L., Bahloul, M., Hakim, A., Dammak, H., Chelly, H., et al. (2007). Safety and efficacy of colistin compared with imipenem in the treatment of ventilator-associated pneumonia: a matched case-control study. Intensive Care Med. 33, 1162-1167. doi: 10.1007/s00134-007-0675-2

Karageorgopoulos, D. E., Miriagou, V., Tzouvelekis, L. S., Spyridopoulou, K., and Daikos, G. L. (2012). Emergence of resistance to fosfomycin used as adjunct therapy in KPC Klebsiella pneumoniae bacteraemia: report of three cases. J. Antimicrob. Chemother. 67, 2777-2779. doi: 10.1093/jac/dks270

Kasiakou, S. K., Fragoulis, K., Tzagarakis, G., Mistidis, P., Kapaskelis, A., and Falagas, M. E. (2005a). Cure of multidrug-resistant Acinetobacter baumanni fixation device-related orthopedic infections in two patients with intravenous colistin. Microb. Drug Resist. 11, 287-289. doi: 10.1089/mdr.2005.11.287

Kasiakou, S. K., Michalopoulos, A., Soteriades, E. S., Samonis, G., Sermaides, G. J., and Falagas, M. E. (2005b). Combination therapy with intravenous colistin for management of infections due to multidrug-resistant Gram-negative bacteria in patients without cystic fibrosis. Antimicrob. Agents Chemother. 49, 3136-3146. doi: 10.1128/AAC.49.8.3136-3146.2005

Katopodis, G. D., Grivea, I. N., Tsantsaridou, A. J., Pournaras, S., Petinaki, E., and Syrogiannopoulos, G. A. (2010). Fusidic acid and clindamycin resistance in community-associated, methicillin-resistant Staphylococcus aureus infections in children of Central Greece. BMC Infect. Dis. 10:351. doi: 10.1186/1471-233410-351

Kawada, H., Yamazato, M., Shinozawa, Y., Suzuki, K., Otani, S., Ouchi, M., et al. (2008). [Achievement of sputum culture negative conversion by minocycline in a case with extensively drug-resistant pulmonary tuberculosis]. Kekkaku 83 , 725-728.

Kefala-Agoropoulou, K., Protonotariou, E., Vitti, D., Sarafidou, S., Anastasiou, A., Kollios, K., et al. (2010). Life-threatening infection due to communityacquired methicillin-resistant Staphylococcus aureus: case report and review. Eur. J. Pediatr. 169, 47-53. doi: 10.1007/s00431-009-0977-1

Klevens, R. M., Morrison, M. A., Nadle, J., Petit, S., Gershman, K., Ray, S., et al. (2007). Invasive methicillin-resistant Staphylococcus aureus infections in the United States. JAMA 298, 1763-1771. doi: 10.1001/jama.298.15.1763

Kofteridis, D. P., Alexopoulou, C., Valachis, A., Maraki, S., Dimopoulou, D., Georgopoulos, D., et al. (2010). Aerosolized plus intravenous colistin versus intravenous colistin alone for the treatment of ventilator-associated pneumonia: a matched case-control study. Clin. Infect. Dis. 51, 1238-1244. doi: $10.1086 / 657242$

Komura, S., and Kurahashi, K. (1979). Partial purification and properties of L2,4-diaminobutyric acid activating enzyme from a polymyxin E producing organism. J. Biochem. 86, 1013-1021.

Kontopidou, F., Giamarellou, H., Katerelos, P., Maragos, A., Kioumis, I., TrikkaGraphakos, E., et al. (2014). Infections caused by carbapenem-resistant Klebsiella pneumoniae among patients in intensive care units in Greece: a multicentre study on clinical outcome and therapeutic options. Clin. Microbiol. Infect. 20, O117-O123. doi: 10.1111/1469-0691.12341

Koomanachai, P., Tiengrim, S., Kiratisin, P., and Thamlikitkul, V. (2007). Efficacy and safety of colistin (colistimethate sodium) for therapy of infections caused by multidrug-resistant Pseudomonas aeruginosa and Acinetobacter baumannii in Siriraj Hospital, Bangkok, Thailand. Int. J. Infect. Dis. 11, 402-406. doi: 10.1016/j.ijid.2006.09.011

Lautenbach, E., Gould, C. V., LaRosa, L. A., Marr, A. M., Nachamkin, I., Bilker, W. B., et al. (2004). Emergence of resistance to chloramphenicol among vancomycin-resistant enterococcal (VRE) bloodstream isolates. Int. J. Antimicrob. Agents 23, 200-203. doi: 10.1016/.ijantimicag.2003.09.011

Lautenbach, E., Schuster, M. G., Bilker, W. B., and Brennan, P. J. (1998). The role of chloramphenicol in the treatment of bloodstream infection due to vancomycinresistant Enterococcus. Clin. Infect. Dis. 27, 1259-1265. doi: 10.1086/ 515002
Lawlor, M. T., Sullivan, M. C., Levitz, R. E., Quintiliani, R., and Nightingale, C. (1990). Treatment of prosthetic valve endocarditis due to methicillinresistant Staphylococcus aureus with minocycline. J. Infect. Dis. 161, 812-814. doi: 10.1093/infdis/161.4.812

Leclercq, R., Soussy, C. J., Weber, P., Moniot-Ville, N., Dib, C., and Groupe d'Etude Multicentrique. (2003). [In vitro activity of the pristinamycin against the isolated staphylococci in the french hospitals in 1999-2000]. Pathol. Biol. 51, 400-404. doi: 10.1016/S0369-8114(03)00054-3

Lee, W.-S., Chen, Y.-C., Chen, H.-P., Chen, T.-H., and Cheng, C.-Y. (2013). Vertebral osteomyelitis caused by vancomycin-tolerant methicillinresistant Staphylococcus aureus bacteremia: experience with teicoplanin plus fosfomycin combination therapy. J. Microbiol. Immunol. Infect. doi: 10.1016/j.jmii.2013.09.002. [Epub ahead of print].

Lee, S.-Y., Park, Y.-J., Yu, J. K., Jung, S., Kim, Y., Jeong, S. H., et al. (2012). Prevalence of acquired fosfomycin resistance among extended-spectrum $\beta$ lactamase-producing Escherichia coli and Klebsiella pneumoniae clinical isolates in Korea and IS26-composite transposon surrounding fosA3. J. Antimicrob. Chemother. 67, 2843-2847. doi: 10.1093/jac/dks319

Levitz, R. E., Dudley, M. N., Quintiliani, R., Mullany, L. D., and Nightingale, C. H. (1984). Cerebrospinal fluid penetration of trimethoprim-sulphamethoxazole in two patients with gram-negative bacillary meningitis. J. Antimicrob. Chemother. 13, 400-401. doi: 10.1093/jac/13.4.400

Li, J., Nation, R. L., Turnidge, J. D., Milne, R. W., Coulthard, K., Rayner, C. R., et al. (2006). Colistin: the re-emerging antibiotic for multidrug-resistant Gramnegative bacterial infections. Lancet Infect. Dis. 6, 589-601. doi: 10.1016/S14733099(06)70580-1

Linden, P. K., Kusne, S., Coley, K., Fontes, P., Kramer, D. J., and Paterson, D. (2003). Use of parenteral colistin for the treatment of serious infection due to antimicrobial-resistant Pseudomonas aeruginosa. Clin. Infect. Dis. 37, e154-e160. doi: 10.1086/379611

Livermore, D. M., Hope, R., Fagan, E. J., Warner, M., Woodford, N., and Potz, N. (2006). Activity of temocillin against prevalent ESBL- and AmpC-producing Enterobacteriaceae from south-east England. J. Antimicrob. Chemother. 57, 1012-1014. doi: 10.1093/jac/dkl043

Livermore, D. M., and Tulkens, P. M. (2009). Temocillin revived. J. Antimicrob. Chemother. 63, 243-245. doi: 10.1093/jac/dkn511

Livermore, D. M., Warner, M., Mushtaq, S., Doumith, M., Zhang, J., and Woodford, N. (2011). What remains against carbapenem-resistant Enterobacteriaceae? Evaluation of chloramphenicol, ciprofloxacin, colistin, fosfomycin, minocycline, nitrofurantoin, temocillin and tigecycline. Int. J. Antimicrob. Agents 37, 415-419. doi: 10.1016/j.ijantimicag.2011.01.012

Long, K. S., and Vester, B. (2012). Resistance to linezolid caused by modifications at its binding site on the ribosome. Antimicrob. Agents Chemother. 56, 603-612. doi: 10.1128/AAC.05702-11

Lu, Q., Luo, R., Bodin, L., Yang, J., Zahr, N., Aubry, A., et al. (2012). Efficacy of high-dose nebulized colistin in ventilator-associated pneumonia caused by multidrug-resistant Pseudomonas aeruginosa and Acinetobacter baumannii. Anesthesiology 117, 1335-1347. doi: 10.1097/ALN.0b013e31827515de

Markou, N., Apostolakos, H., Koumoudiou, C., Athanasiou, M., Koutsoukou, A., Alamanos, I., et al. (2003). Intravenous colistin in the treatment of sepsis from multiresistant Gram-negative bacilli in critically ill patients. Crit Care 7, R78-R83. doi: 10.1186/cc2358

Markowitz, N., Quinn, E. L., and Saravolatz, L. D. (1992). Trimethoprimsulfamethoxazole compared with vancomycin for the treatment of Staphylococcus aureus infection. Ann. Intern. Med. 117, 390-398. doi: 10. 7326/0003-4819-117-5-390

Martínez-Aguilar, G., Hammerman, W. A., Mason, E. O., and Kaplan, S. L. (2003). Clindamycin treatment of invasive infections caused by communityacquired, methicillin-resistant and methicillin-susceptible Staphylococcus aureus in children. Pediatr. Infect. Dis. J. 22, 593-598. doi: 10.1097/01.inf.0000073163. 37519.ee

Mastoraki, A., Douka, E., Kriaras, I., Stravopodis, G., Manoli, H., and Geroulanos, S. (2008). Pseudomonas aeruginosa susceptible only to colistin in intensive care unit patients. Surg. Infect. (Larchmt.) 9, 153-160. doi: 10.1089/sur. 2007.004

McGehee, R. F., Smith, C. B., Wilcox, C., and Finland, M. (1968). Comparative studies of antibacterial activity in vitro and absorption and excretion of lincomycin and clinimycin. Am. J. Med. Sci. 256, 279-292. doi: 10.1097/00000441196811000-00002 
Mehta, N. J., Khan, I. A., Mehta, R. N., and Gulati, A. (2000). Stenotrophomonas maltophilia endocarditis of prosthetic aortic valve: report of a case and review of literature. Heart Lung 29, 351-355. doi: 10.1067/mhl.2000.108362

Merkier, A. K., Rodríguez, M. C., Togneri, A., Brengi, S., Osuna, C., Pichel, M., et al. (2013). Outbreak of a cluster with epidemic behavior due to Serratia marcescens after colistin administration in a hospital setting. J. Clin. Microbiol. 51, 2295-2302. doi: 10.1128/JCM.03280-12

Messina, A. F., Namtu, K., Guild, M., Dumois, J. A., and Berman, D. M. (2011). Trimethoprim-sulfamethoxazole therapy for children with acute osteomyelitis. Pediatr. Infect. Dis. J. 30, 1019-1021. doi: 10.1097/INF.0b013e31822db658

Michalopoulos, A. S., and Falagas, M. E. (2014). Inhaled antibiotics in mechanically ventilated patients. Minerva Anestesiol. 80, 236-244.

Michalopoulos, A., Virtzili, S., Rafailidis, P., Chalevelakis, G., Damala, M., and Falagas, M. E. (2010). Intravenous fosfomycin for the treatment of nosocomial infections caused by carbapenem-resistant Klebsiella pneumoniae in critically ill patients: a prospective evaluation. Clin. Microbiol. Infect. 16, 184-186. doi: 10.1111/j.1469-0691.2009.02921.x

Mirakhur, A., Gallagher, M. J., Ledson, M. J., Hart, C. A., and Walshaw, M. J. (2003). Fosfomycin therapy for multiresistant Pseudomonas aeruginosa in cystic fibrosis. J. Cyst. Fibros. 2, 19-24. doi: 10.1016/S1569-1993(02)00143-1

Mitnick, C. D., Shin, S. S., Seung, K. J., Rich, M. L., Atwood, S. S., Furin, J. J., et al. (2008). Comprehensive treatment of extensively drug-resistant tuberculosis. N. Engl. J. Med. 359, 563-574. doi: 10.1056/NEJMoa0800106

Mohamed, A. F., Karaiskos, I., Plachouras, D., Karvanen, M., Pontikis, K., Jansson, B., et al. (2012). Application of a loading dose of colistin methanesulfonate in critically ill patients: population pharmacokinetics, protein binding, and prediction of bacterial kill. Antimicrob. Agents Chemother. 56, 4241-4249. doi: 10.1128/AAC.06426-11

Moran, G. J., Krishnadasan, A., Gorwitz, R. J., Fosheim, G. E., McDougal, L. K., Carey, R. B., et al. (2006). Methicillin-resistant S. aureus infections among patients in the emergency department. N. Engl. J. Med. 355, 666-674. doi: 10.1056/NEJMoa055356

Moreno, F., Jorgensen, J. H., and Weiner, M. H. (1994). An old antibiotic for a new multiple-resistant Enterococcus faecium? Diagn. Microbiol. Infect. Dis. 20, 41-43. doi: 10.1016/0732-8893(94)90017-5

Motaouakkil, S., Charra, B., Hachimi, A., Nejmi, H., Benslama, A., Elmdaghri, N., et al. (2006). Colistin and rifampicin in the treatment of nosocomial infections from multiresistant Acinetobacter baumannii. J. Infect. 53, 274-278. doi: 10.1016/j.jinf.2005.11.019

Mouton, J. W., Ambrose, P. G., Canton, R., Drusano, G. L., Harbarth, S., MacGowan, A., et al. (2011). Conserving antibiotics for the future: new ways to use old and new drugs from a pharmacokinetic and pharmacodynamic perspective. Drug Resist. Updat. 14, 107-117. doi: 10.1016/j.drup.2011.02.005

Muhammed Ameen, S., Rolain, J.-M., Le Poullain, M.-N., Roux, V., Raoult, D., and Drancourt, M. (2014). Serum concentration of co-trimoxazole during a highdosage regimen. J. Antimicrob. Chemother. 69, 757-760. doi: 10.1093/jac/dkt400

Murray, R. J., Pearson, J. C., Coombs, G. W., Flexman, J. P., Golledge, C. L., Speers, D. J., et al. (2008). Outbreak of invasive methicillin-resistant Staphylococcus aureus infection associated with acupuncture and joint injection. Infect. Control Hosp. Epidemiol. 29, 859-865. doi: 10.1086/590260

Nadler, J. P., Berger, J., Nord, J. A., Cofsky, R., and Saxena, M. (1991). Amoxicillinclavulanic acid for treating drug-resistant Mycobacterium tuberculosis. Chest 99 1025-1026. doi: 10.1378/chest.99.4.1025

Nakaya, H., Yasuhara, A., Yoshimura, K., Oshihoi, Y., Izumiya, H., and Watanabe, H. (2003). Life-threatening infantile diarrhea from fluoroquinolone-resistant Salmonella enterica typhimurium with mutations in both gyrA and parC. Emerging Infect. Dis. 9, 255-257. doi: 10.3201/eid0902.020185

Nather, A., David, V., Hee, H. T., and Thambiah, J. (2005). Pyogenic vertebral osteomyelitis: a review of 14 cases. J. Orthop. Surg. (Hong Kong) 13, 240-244.

Navarro-San Francisco, C., Mora-Rillo, M., Romero-Gómez, M. P., MorenoRamos, F., Rico-Nieto, A., Ruiz-Carrascoso, G., et al. (2013). Bacteraemia due to OXA-48-carbapenemase-producing Enterobacteriaceae: a major clinical challenge. Clin. Microbiol. Infect. 19, E72-E79. doi: 10.1111/1469-0691.12091

Nelson, M. L., and Levy, S. B. (2011). The history of the tetracyclines. Ann. N.Y. Acad. Sci. 1241, 17-32. doi: 10.1111/j.1749-6632.2011.06354.x

Neuner, E. A., Sekeres, J., Hall, G. S., and van Duin, D. (2012). Experience with fosfomycin for treatment of urinary tract infections due to multidrugresistant organisms. Antimicrob. Agents Chemother. 56, 5744-5748. doi: 10.1128/AAC.00402-12
Ng, J., and Gosbell, I. B. (2005). Successful oral pristinamycin therapy for osteoarticular infections due to methicillin-resistant Staphylococcus aureus (MRSA) and other Staphylococcus spp. J. Antimicrob. Chemother. 55, 1008-1012. doi: 10.1093/jac/dki108

Nguyen, S., Pasquet, A., Legout, L., Beltrand, E., Dubreuil, L., Migaud, H., et al. (2009). Efficacy and tolerance of rifampicin-linezolid compared with rifampicin-cotrimoxazole combinations in prolonged oral therapy for bone and joint infections. Clin. Microbiol. Infect. 15, 1163-1169. doi: 10.1111/j.14690691.2009.02761.x

Nicolle, L. E., and Mulvey, M. R. (2007). Successful treatment of ctx-m ESBL producing Escherichia coli relapsing pyelonephritis with long term pivmecillinam. Scand. J. Infect. Dis. 39, 748-749. doi: 10.1080/00365540701367801

Norris, A. H., Reilly, J. P., Edelstein, P. H., Brennan, P. J., and Schuster, M. G. (1995). Chloramphenicol for the treatment of vancomycin-resistant enterococcal infections. Clin. Infect. Dis. 20, 1137-1144. doi: 10.1093/clinids/20.5.1137

O’Neill, B. J., Hirpara, K. M., and Kaar, T. K. (2011). Successful treatment of chronic osteomyelitis of the radius. ISRN Pediatr. 2011:154878. doi: $10.5402 / 2011 / 154878$

Oostdijk, E. A. N., Smits, L., de Smet, A. M. G. A., Leverstein-van Hall, M. A., Kesecioglu, J., and Bonten, M. J. M. (2013). Colistin resistance in gram-negative bacteria during prophylactic topical colistin use in intensive care units. Intensive Care Med. 39, 653-660. doi: 10.1007/s00134-012-2761-3

Park, Y. K., Choi, J. Y., Shin, D., and Ko, K. S. (2011). Correlation between overexpression and amino acid substitution of the PmrAB locus and colistin resistance in Acinetobacter baumannii. Int. J. Antimicrob. Agents 37, 525-530. doi: 10.1016/j.ijantimicag.2011.02.008

Patel, S. N., Memari, N., Shahinas, D., Toye, B., Jamieson, F. B., and Farrell, D. J. (2013). Linezolid resistance in Enterococcus faecium isolated in Ontario, Canada. Diagn. Microbiol. Infect. Dis. 77, 350-353. doi: 10.1016/j.diagmicrobio.2013.08.012

Pea, F., and Viale, P. (2007). Pharmacodynamics of antibiotics to treat multidrugresistant Gram-positive hospital infections. Expert Rev. Anti Infect. Ther. 5, 255-270. doi: 10.1586/14787210.5.2.255

Pérez Mato, S., Robinson, S., and Bégué, R. E. (1999). Vancomycin-resistant Enterococcus faecium meningitis successfully treated with chloramphenicol. Pediatr. Infect. Dis. J. 18, 483-484. doi: 10.1097/00006454-199905000-00023

Pfaller, M. A., Castanheira, M., Sader, H. S., and Jones, R. N. (2010). Evaluation of the activity of fusidic acid tested against contemporary Gram-positive clinical isolates from the USA and Canada. Int. J. Antimicrob. Agents 35, 282-287. doi: 10.1016/j.ijantimicag.2009.10.023

Pitout, J. D. D., and Laupland, K. B. (2008). Extended-spectrum beta-lactamaseproducing Enterobacteriaceae: an emerging public-health concern. Lancet Infect. Dis. 8, 159-166. doi: 10.1016/S1473-3099(08)70041-0

Pogue, J. M., Marchaim, D., Kaye, D., and Kaye, K. S. (2011). Revisiting “older" antimicrobials in the era of multidrug resistance. Pharmacotherapy 31, 912-921. doi: 10.1592/phco.31.9.912

Pontikis, K., Karaiskos, I., Bastani, S., Dimopoulos, G., Kalogirou, M., Katsiari, M., et al. (2014). Outcomes of critically ill intensive care unit patients treated with fosfomycin for infections due to pandrug-resistant and extensively drugresistant carbapenemase-producing Gram-negative bacteria. Int. J. Antimicrob Agents 43, 52-59. doi: 10.1016/j.ijantimicag.2013.09.010

Poulsen, H. O., Johansson, A., Granholm, S., Kahlmeter, G., and Sundqvist, M. (2013). High genetic diversity of nitrofurantoin- or mecillinam-resistant Escherichia coli indicates low propensity for clonal spread. J. Antimicrob. Chemother. 68, 1974-1977. doi: 10.1093/jac/dkt159

Pound, M. W., Tart, S. B., and Okoye, O. (2007). Multidrug-resistant Ewingella americana: a case report and review of the literature. Ann. Pharmacother. 41 , 2066-2070. doi: 10.1345/aph.1K398

Proctor, R. A. (2008). Role of folate antagonists in the treatment of methicillinresistant Staphylococcus aureus infection. Clin. Infect. Dis. 46, 584-593. doi: $10.1086 / 525536$

Pulcini, C., Bush, K., Craig, W. A., Frimodt-Møller, N., Grayson, M. L., Mouton, J. W., et al. (2012). Forgotten antibiotics: an inventory in Europe, the United States, Canada, and Australia. Clin. Infect. Dis. 54, 268-274. doi: $10.1093 / \mathrm{cid} / \mathrm{cir} 838$

Pullukcu, H., Tasbakan, M., Sipahi, O. R., Yamazhan, T., Aydemir, S., and Ulusoy, S. (2007). Fosfomycin in the treatment of extended spectrum betalactamase-producing Escherichia coli-related lower urinary tract infections. Int. J. Antimicrob. Agents 29, 62-65. doi: 10.1016/j.ijantimicag.2006.08.039 
Quentin, C., Grobost, F., Fischer, I., Dutilh, B., Brochet, J. P., Jullin, J., et al. (2001). [Antibiotic resistance of Staphylococcus aureus in urban experience: 6 month study in Aquitaine]. Pathol. Biol. 49, 33-40. doi: 10.1016/S0369-8114(00)00008-

Raz, R. (2012). Fosfomycin: an old-new antibiotic. Clin. Microbiol. Infect. 18, 4-7. doi: 10.1111/j.1469-0691.2011.03636.x

Reed, M. D., Stern, R. C., O’Riordan, M. A., and Blumer, J. L. (2001). The pharmacokinetics of colistin in patients with cystic fibrosis. J. Clin. Pharmacol. 41, 645-654. doi: 10.1177/00912700122010537

Reid, A. B., Daffy, J. R., Stanley, P., and Buising, K. L. (2010). Use of pristinamycin for infections by gram-positive bacteria: clinical experience at an Australian hospital. Antimicrob. Agents Chemother. 54, 3949-3952. doi: 10.1128/AAC. 00212-10

Ricaurte, J. C., Boucher, H. W., Turett, G. S., Moellering, R. C., Labombardi, V. J., and Kislak, J. W. (2001). Chloramphenicol treatment for vancomycinresistant Enterococcus faecium bacteremia. Clin. Microbiol. Infect. 7, 17-21. doi: 10.1046/j.1469-0691.2001.00189.x

Rios, F. G., Luna, C. M., Maskin, B., Saenz Valiente, A., Lloria, M., Gando, S., et al. (2007). Ventilator-associated pneumonia due to colistin susceptible-only microorganisms. Eur. Respir. J. 30, 307-313. doi: 10.1183/09031936.00156906

Roberts, M. C. (2008). Update on macrolide-lincosamide-streptogramin, ketolide, and oxazolidinone resistance genes. FEMS Microbiol. Lett. 282, 147-159. doi: 10.1111/j.1574-6968.2008.01145.x

Rodríguez, A., Gallego, A., Olay, T., and Mata, J. M. (1977). Bacteriological evaluation of fosfomycin in clinical studies. Chemotherapy 23(Suppl. 1), 247-258. doi: $10.1159 / 000222055$

Rodriguez-Villalobos, H., Malaviolle, V., Frankard, J., de Mendonça, R., Nonhoff, C., and Struelens, M. J. (2006). In vitro activity of temocillin against extended spectrum beta-lactamase-producing Escherichia coli. J. Antimicrob. Chemother. 57, 771-774. doi: 10.1093/jac/dkl046

Rolain, J.-M., Diene, S. M., Kempf, M., Gimenez, G., Robert, C., and Raoult, D. (2013). Real-time sequencing to decipher the molecular mechanism of resistance of a clinical pan-drug-resistant Acinetobacter baumannii isolate from Marseille, France. Antimicrob. Agents Chemother. 57, 592-596. doi: 10.1128/AAC.01314-12

Rolain, J.-M., Roch, A., Castanier, M., Papazian, L., and Raoult, D. (2011). Acinetobacter baumannii resistant to colistin with impaired virulence: a case report from France. J. Infect. Dis. 204, 1146-1147. doi: 10.1093/infdis/jir475

Roualdes, G., Lartigue, C., Boudigue, M. D., and Maissin, F. (1985). [Infection of the valves of CSF shunts. Results of local and general antibiotic treatment in 6 cases]. Neurochirurgie 31, 390-394.

Ruhe, J. J., and Menon, A. (2007). Tetracyclines as an oral treatment option for patients with community onset skin and soft tissue infections caused by methicillin-resistant Staphylococcus aureus. Antimicrob. Agents Chemother. 51, 3298-3303. doi: 10.1128/AAC.00262-07

Ruhe, J. J., Monson, T., Bradsher, R. W., and Menon, A. (2005). Use of longacting tetracyclines for methicillin-resistant Staphylococcus aureus infections: case series and review of the literature. Clin. Infect. Dis. 40, 1429-1434. doi: $10.1086 / 429628$

Ruhe, J. J., Smith, N., Bradsher, R. W., and Menon, A. (2007). Communityonset methicillin-resistant Staphylococcus aureus skin and soft-tissue infections: impact of antimicrobial therapy on outcome. Clin. Infect. Dis. 44, 777-784. doi: $10.1086 / 511872$

Ruparelia, N., Atkins, B. L., Hemingway, J., Berendt, A. R., and Byren, I. (2008). Pristinamycin as adjunctive therapy in the management of Gram-positive multi-drug resistant organism (MDRO) osteoarticular infection. J. Infect. 57, 191-197. doi: 10.1016/j.jinf.2008.07.002

Sandegren, L., Lindqvist, A., Kahlmeter, G., and Andersson, D. I. (2008). Nitrofurantoin resistance mechanism and fitness cost in Escherichia coli. J. Antimicrob. Chemother. 62, 495-503. doi: 10.1093/jac/dkn222

Scapellato, P. G., Ormazabal, C., Scapellato, J. L., and Bottaro, E. G. (2005). Meningitis due to vancomycin-resistant Enterococcus faecium successfully treated with combined intravenous and intraventricular chloramphenicol. J. Clin. Microbiol. 43, 3578-3579. doi: 10.1128/JCM.43.7.3578-3579.2005

Schwartz, B. S., Graber, C. J., Diep, B. A., Basuino, L., Perdreau-Remington, F., and Chambers, H. F. (2009). Doxycycline, not minocycline, induces its own resistance in multidrug-resistant, community-associated methicillin-resistant Staphylococcus aureus clone USA300. Clin. Infect. Dis. 48, 1483-1484. doi: $10.1086 / 598510$
Seligman, S. J., Madhavan, T., and Alcid, D. (1973). Trimethoprimsulfamethoxazole in the treatment of bacterial endocarditis. J. Infect. Dis. 128, Suppl:754-761 p.

Senol, S., Tasbakan, M., Pullukcu, H., Sipahi, O. R., Sipahi, H., Yamazhan, T., et al. (2010). Carbapenem versus fosfomycin tromethanol in the treatment of extended-spectrum beta-lactamase-producing Escherichia coli-related complicated lower urinary tract infection. J. Chemother. 22, 355-357. doi: 10.1179/joc.2010.22.5.355

Seppälä, H., Klaukka, T., Vuopio-Varkila, J., Muotiala, A., Helenius, H., Lager, K., et al. (1997). The effect of changes in the consumption of macrolide antibiotics on erythromycin resistance in group A streptococci in Finland. Finnish Study Group for Antimicrobial Resistance. N. Engl. J. Med. 337, 441-446. doi: 10.1056/NEJM199708143370701

Shafqat, S. H., Shah, S. A., and Seyed, S. A. (1971). Bacterial endocarditis over prosthetic valves treated with trimethoprim-sulphamethoxazole combination. Br. Heart J. 33, 974-976. doi: 10.1136/hrt.33.6.974

Shean, K., Streicher, E., Pieterson, E., Symons, G., van Zyl Smit, R., Theron, G., et al. (2013). Drug-associated adverse events and their relationship with outcomes in patients receiving treatment for extensively drug-resistant tuberculosis in South Africa. PLoS One 8:e63057. doi: 10.1371/journal.pone.0063057

Siberry, G. K., Tekle, T., Carroll, K., and Dick, J. (2003). Failure of clindamycin treatment of methicillin-resistant Staphylococcus aureus expressing inducible clindamycin resistance in vitro. Clin. Infect. Dis. 37, 1257-1260. doi: $10.1086 / 377501$

Silbermann, M. H., Gyssens, I. C., Wielenga, J. J., Endtz, H. P., and Löwenberg, B. (1995). [A patient with acute leukemia and meningitis caused by Staphylococcus epidermidis treated with fosfomycin]. Ned. Tijdschr. Geneeskd. 139, 2498-2501.

Slocombe, B., Basker, M. J., Bentley, P. H., Clayton, J. P., Cole, M., Comber, K. R., et al. (1981). BRL 17421, a novel beta-lactam antibiotic, highly resistant to beta-lactamases, giving high and prolonged serum levels in humans. Antimicrob. Agents Chemother. 20, 38-46. doi: 10.1128/AAC.20.1.38

Song, J. Y., Lee, J., Heo, J. Y., Noh, J. Y., Kim, W. J., Cheong, H. J., et al. (2008). Colistin and rifampicin combination in the treatment of ventilator-associated pneumonia caused by carbapenem-resistant Acinetobacter baumannii. Int. J. Antimicrob. Agents 32, 281-284. doi: 10.1016/j.ijantimicag.2008.04.013

Søraas, A., Sundsfjord, A., Jørgensen, S. B., Liestøl, K., and Jenum, P. A. (2014). High rate of per oral mecillinam treatment failure in community-acquired urinary tract infections caused by ESBL-producing Escherichia coli. PLoS ONE 9:e85889. doi: 10.1371/journal.pone.0085889

Spellberg, B., Powers, J. H., Brass, E. P., Miller, L. G., and Edwards, J. E. (2004). Trends in antimicrobial drug development: implications for the future. Clin. Infect. Dis. 38, 1279-1286. doi: 10.1086/420937

Stein, A., Bataille, J. F., Drancourt, M., Curvale, G., Argenson, J. N., Groulier, P., et al. (1998). Ambulatory treatment of multidrug-resistant Staphylococcus-infected orthopedic implants with high-dose oral cotrimoxazole (trimethoprim-sulfamethoxazole). Antimicrob. Agents Chemother. 42, 3086-3091.

Stevens, D. L., Bisno, A. L., Chambers, H. F., Dellinger, E. P., Goldstein, E. J. C., Gorbach, S. L., et al. (2014). Practice guidelines for the diagnosis and management of skin and soft tissue infections: 2014 update by the Infectious Diseases Society of America. Clin. Infect. Dis. 59, 147-159. doi: 10.1093/cid/ciu296

Suárez, J. E., and Mendoza, M. C. (1991). Plasmid-encoded fosfomycin resistance. Antimicrob. Agents Chemother. 35, 791-795. doi: 10.1128/AAC.35.5.791

Sullivan, A., Edlund, C., and Nord, C. E. (2001). Effect of antimicrobial agents on the ecological balance of human microflora. Lancet Infect. Dis. 1, 101-114. doi: 10.1016/S1473-3099(01)00066-4

Tamer, M. A., and Bray, J. D. (1982). Trimethoprim-sulfamethoxazole treatment of multiantibiotic-resistant staphylococcal endocarditis and meningitis. Clin. Pediatr. (Phila.) 21, 125-126. doi: 10.1177/000992288202100211

Tasbakan, M. I., Pullukcu, H., Sipahi, O. R., Yamazhan, T., and Ulusoy, S. (2012). Nitrofurantoin in the treatment of extended-spectrum $\beta$-lactamase-producing Escherichia coli-related lower urinary tract infection. Int. J. Antimicrob. Agents 40, 554-556. doi: 10.1016/j.ijantimicag.2012.08.003

Taşbakan, M. S., Pullukçu, H., Ekren, P. K., Oz, A. T., Midilli, M., Aydemir, S., et al. (2009). [Colistin use in ventilator-associated pneumonia due to panresistant Pseudomonas aeruginosa and Acinetobacter baumannii]. Mikrobiyol. Bul. $43,61-70$

Tascini, C., Gemignani, G., Palumbo, F., Leonildi, A., Tedeschi, A., Lambelet, P., et al. (2006). Clinical and microbiological efficacy of colistin therapy alone or in 
combination as treatment for multidrug resistant Pseudomonas aeruginosa diabetic foot infections with or without osteomyelitis. J. Chemother. 18, 648-651. doi: 10.1179/joc.2006.18.6.648

Taylor, S. E., Paterson, D. L., and Yu, V. L. (1998). Treatment options for chronic prostatitis due to vancomycin-resistant Enterococcus faecium. Eur. J. Clin. Microbiol. Infect. Dis. 17, 798-800. doi: 10.1007/s100960050190

Titelman, E., Iversen, A., Kalin, M., and Giske, C. G. (2012). Efficacy of pivmecillinam for treatment of lower urinary tract infection caused by extendedspectrum $\beta$-lactamase-producing Escherichia coli and Klebsiella pneumoniae. Microb. Drug Resist. 18, 189-192. doi: 10.1089/mdr.2011.0161

Tobeña Rué, M., Coll Usandizaga, F., García Fontecha, C., Bartolomé Comas, R., and Moraga Llop, F. A. (2009). [Necrotizing fasciitis due to communityacquired panton-valentine leukocidin methicillin resistant Staphylococcus aureus]. An. Pediatr. (Barc). 70, 374-378. doi: 10.1016/j.anpedi.2008.11.027

Trzcinski, K., Cooper, B. S., Hryniewicz, W., and Dowson, C. G. (2000). Expression of resistance to tetracyclines in strains of methicillin-resistant Staphylococcus aureus. J. Antimicrob. Chemother. 45, 763-770. doi: 10.1093/jac/45.6.763

Tsukamura, M., Mizuno, S., and Toyama, H. (1983). [Combined effect of minocycline with antitubercular agents on Mycobacterium tuberculosis: in vitro study]. Kekkaku 58, 665-667.

Tumbarello, M., De Pascale, G., Trecarichi, E. M., De Martino, S., Bello, G., Maviglia, R., et al. (2013). Effect of aerosolized colistin as adjunctive treatment on the outcomes of microbiologically documented ventilator-associated pneumonia caused by colistin-only susceptible gram-negative bacteria. Chest 144 1768-1775. doi: 10.1378/chest.13-1018

Turnidge, J. (1999). Fusidic acid pharmacology, pharmacokinetics and pharmacodynamics. Int. J. Antimicrob. Agents 12(Suppl. 2), S23-S34. doi: 10.1016/S09248579(98)00071-5

Tuzuner-Oncul, A. M., Ungor, C., Dede, U., and Kisnisci, R. S. (2009). Methicillinresistant Staphylococcus aureus (MRSA) osteomyelitis of the mandible. Oral Surg. Oral Med. Oral Pathol. Oral Radiol. Endod. 107, e1-e4. doi: 10.1016/j.tripleo.2009.03.002

Udo, E. E., Al-Sweih, N., Mokaddas, E., Johny, M., Dhar, R., Gomaa, H. H., et al. (2006). Antibacterial resistance and their genetic location in MRSA isolated in Kuwait hospitals, 1994-2004. BMC Infect. Dis. 6:168. doi: 10.1186/14712334-6-168

Van der Veen, E. L., Schilder, A. G. M., Timmers, T. K., Rovers, M. M., Fluit, A. C., Bonten, M. J., et al. (2009). Effect of long-term trimethoprim/sulfamethoxazole treatment on resistance and integron prevalence in the intestinal flora: a randomized, double-blind, placebo-controlled trial in children. J. Antimicrob. Chemother. 63, 1011-1016. doi: 10.1093/jac/dkp050

Van Deun, A., Maug, A. K. J., Salim, M. A. H., Das, P. K., Sarker, M. R., Daru, P., et al. (2010). Short, highly effective, and inexpensive standardized treatment of multidrug-resistant tuberculosis. Am. J. Respir. Crit. Care Med. 182, 684-692. doi: 10.1164/rccm.201001-0077OC

Wachi, M., Doi, M., Tamaki, S., Park, W., Nakajima-Iijima, S., and Matsuhashi, M. (1987). Mutant isolation and molecular cloning of mre genes, which determine cell shape, sensitivity to mecillinam, and amount of penicillin-binding proteins in Escherichia coli. J. Bacteriol. 169, 4935-4940.

Walker, B., Barrett, S., Polasky, S., Galaz, V., Folke, C., Engström, G., et al. (2009). Environment. Looming global-scale failures and missing institutions. Science 325, 1345-1346. doi: 10.1126/science.1175325

Wang, J.-L., Tang, H.-J., Hsieh, P.-H., Chiu, F.-Y., Chen, Y.-H., Chang, M.-C., et al. (2012). Fusidic acid for the treatment of bone and joint infections caused by meticillin-resistant Staphylococcus aureus. Int. J. Antimicrob. Agents 40, 103-107. doi: 10.1016/j.ijantimicag.2012.03.010
Wasyl, D., Hoszowski, A., Zajac, M., and Szulowski, K. (2013). Antimicrobial resistance in commensal Escherichia coli isolated from animals at slaughter. Front Microbiol 4:221. doi: 10.3389/fmicb.2013.00221

Williamson, D. A., Monecke, S., Heffernan, H., Ritchie, S. R., Roberts, S. A., Upton, A., et al. (2014). High usage of topical fusidic acid and rapid clonal expansion of fusidic acid-resistant Staphylococcus aureus: a cautionary tale. Clin. Infect. Dis. doi: 10.1093/cid/ciu658. [Epub ahead of print].

Wolfe, C. R. (2011). Case report: treatment of chronic osteomyelitis. Clin. Infect. Dis. 52, S538-S541. doi: 10.1093/cid/cir169

Wood, J. B., Smith, D. B., Baker, E. H., Brecher, S. M., and Gupta, K. (2012). Has the emergence of community-associated methicillin-resistant Staphylococcus aureus increased trimethoprim-sulfamethoxazole use and resistance?: a 10year time series analysis. Antimicrob. Agents Chemother. 56, 5655-5660. doi: 10.1128/AAC.01011-12

Xu, H.-B., Jiang, R.-H., and Xiao, H.-P. (2012). Clofazimine in the treatment of multidrug-resistant tuberculosis. Clin. Microbiol. Infect. 18, 1104-1110. doi: 10.1111/j.1469-0691.2011.03716.x

Xu, H., Miao, V., Kwong, W., Xia, R., and Davies, J. (2011). Identification of a novel fosfomycin resistance gene (fosA2) in Enterobacter cloacae from the Salmon River, Canada. Lett. Appl. Microbiol. 52, 427-429. doi: 10.1111/j.1472765X.2011.03016.x

Xu, X., Chen, C., Lin, D., Guo, Q., Hu, F., Zhu, D., et al. (2013). The fosfomycin resistance gene fosB3 is located on a transferable, extrachromosomal circular intermediate in clinical Enterococcus faecium isolates. PLoS ONE 8:e78106. doi: 10.1371/journal.pone.0078106

Yoo, J.-W., Lyu, J., Lee, S. D., Kim, W. S., Kim, D. S., and Shim, T. S. (2013). Clinical experience of using clofazimine to treat multidrug-resistant tuberculosis [Correspondence]. Int. J. Tuberc. Lung Dis. 17, 1243-1244. doi: 10.5588/ijtld.13.0312

Zahar, J.-R., Lortholary, O., Martin, C., Potel, G., Plesiat, P., and Nordmann, P. (2009). Addressing the challenge of extended-spectrum beta-lactamases. Curr. Opin. Investig. Drugs 10, 172-180.

Zhanel, G. G., Laing, N. M., Nichol, K. A., Palatnick, L. P., Noreddin, A., Hisanaga, T., et al. (2003). Antibiotic activity against urinary tract infection (UTI) isolates of vancomycin-resistant enterococci (VRE): results from the 2002 North American Vancomycin Resistant Enterococci Susceptibility Study (NAVRESS). J. Antimicrob. Chemother. 52, 382-388. doi: 10.1093/jac/ dkg352

Conflict of Interest Statement: The authors declare that the research was conducted in the absence of any commercial or financial relationships that could be construed as a potential conflict of interest.

Received: 10 July 2014; accepted: 02 October 2014; published online: 20 October 2014 Citation: Cassir N, Rolain J-M and Brouqui P (2014) A new strategy to fight antimicrobial resistance: the revival of old antibiotics. Front. Microbiol. 5:551. doi: 10.3389/ fmicb.2014.00551

This article was submitted to Antimicrobials, Resistance and Chemotherapy, a section of the journal Frontiers in Microbiology.

Copyright (c) 2014 Cassir, Rolain and Brouqui. This is an open-access article distributed under the terms of the Creative Commons Attribution License (CC BY). The use, distribution or reproduction in other forums is permitted, provided the original author(s) or licensor are credited and that the original publication in this journal is cited, in accordance with accepted academic practice. No use, distribution or reproduction is permitted which does not comply with these terms. 